\title{
The relationship between the level of exercise and hemoglobin A1c in patients with type 2 diabetes mellitus: A systematic review and meta-analysis
}

Yutaka Igarashi ( $\square$ yu_igarashi_000@mail.goo.ne.jp )

Osaka City University https://orcid.org/0000-0003-0012-4225

Nobuhiko Akazawa

Japan Institute of Sports Sciences

Seiji Maeda

University of Tsukuba

\section{Research Article}

Keywords: Improvement Heterogeneity, Meta-regression Analysis, Duration of Exercise

Posted Date: April 28th, 2021

DOI: https://doi.org/10.21203/rs.3.rs-417879/v1

License: (c) (i) This work is licensed under a Creative Commons Attribution 4.0 International License. Read Full License

Version of Record: A version of this preprint was published at Endocrine on July 23rd, 2021. See the published version at https://doi.org/10.1007/s12020-021-02817-8. 


\section{Abstract}

Background: Several systematic reviews and meta-analyses reported that exercise improved hemoglobin $\mathrm{A}_{1} \mathrm{c}\left(\mathrm{HbA}_{1 \mathrm{c}}\right)$ in patients with type 2 diabetes mellitus, but the improvement reported was heterogeneous. A difference in the level of exercise might be the reason for that heterogeneity.

Objective: The aim of study was to evaluate the relationship between changes in $\mathrm{HbA}_{1 \mathrm{c}}$ and exercise levels when performing various types of exercise.

Methods: The inclusion criteria were randomized controlled trials involving adults with type 2 diabetes mellitus and a mean age of $\geq 18$ years, intervention involving exercise alone, the overall duration of intervention $\geq 12$ weeks, and reporting $\mathrm{HbA}_{1 \mathrm{c}}$. The mean difference (defined as difference [intervention group value minus control group value] in change [final value minus baseline value] in the mean value) was calculated. Weighted mean difference (WMD) was defined as the mean difference weighted by the inverse of the squared standard error for each study, and all WMDs were pooled as overall effects. A meta-regression analysis was performed to evaluate the relationship between the exercise level and the WMD in $\mathrm{HbA}_{1 \mathrm{c}}$. All analyses were performed using restricted maximum likelihood.

Results: Forty-eight studies (2395 subjects) were analyzed. The pooled WMD in $\mathrm{HbA}_{1 \mathrm{c}}$ decreased significantly $(-0.5 \%$ [95\% confidence intervals: -0.6 to -0.4$)]$ ) but contained significant heterogeneity $\left(Q=103.8, P<0.01 ; I^{2}=36.6 \%\right)$. The pooled WMD in body mass index (BMI) decreased significantly $\left(-0.55 \mathrm{~kg} / \mathrm{m}^{2}\right.$ [95\% confidence intervals: -0.58 to -0.51$\left.]\right)$ and did not contain heterogeneity $\left(Q=25.8, P=0.99 ; I^{2}=0.0 \%\right)$. A meta-regression analysis showed that the intensity (metabolic equivalents [METs]), time (min/session), or frequency (sessions/week) of exercise was not associated with the $\mathrm{HbA}_{1 \mathrm{c}}$. However, the overall duration of exercise (weeks) was significantly associated with the WMD in $\mathrm{HbA}_{1 \mathrm{c}}$ (meta-regression coefficient: 0.01 [95\% confidence intervals: 0.002 to 0.016 ]; $R^{2}=70.0 \%$ ), and that result did not contain significant heterogeneity $\left(P>0.05 ; I^{2}=14.7 \%\right)$. Even when studies were limited to those involving mean age $\geq 40$ years, mean baseline $\mathrm{HbA}_{1 \mathrm{c}} \geq 6.5 \%$, mean duration of type 2 diabetes mellitus $\geq 5.0$ years, mean baseline $\mathrm{BMI} \geq 30 \mathrm{~kg} / \mathrm{m}^{2}$, calculation of the WMD in BMI, performance of aerobic exercise alone, or no inclusion of a high risk of bias, there was no change in these results.

Conclusions: The exercise intervention decreased $\mathrm{HbA}_{1 \mathrm{c}}$ in type 2 diabetes mellitus patients, but that change likely depended on the overall duration of exercise. $\mathrm{HbA}_{1 \mathrm{c}}$ may increase if exercise is continued, but at least continuing exercise is not necessarily beneficial for type 2 diabetes mellitus patients. This may be the result of intervention in the form of exercise alone.

\section{Key Points}

पThe intensity (METs), time (min/session), or frequency (sessions/week) of exercise was not associated with the $\mathrm{HbA}_{1 \mathrm{c}}$ in type 2 diabetes mellitus patients.

$\square$ Since the overall duration of exercise (weeks) was associated with the $\mathrm{HbA}_{1 c}$, continuing exercise may not necessarily be beneficial for type 2 diabetes mellitus patients.

\section{Introduction}

According to the International Diabetes Federation (IDF), an estimated 4.6 hundred million people around the world have diabetes, and approximately $90 \%$ of them have type 2 diabetes mellitus (T2DM) [1]. T2DM contributes to cardiovascular disease, cancer, dementia, and worse morbidity and mortality [2-7]. As an example, a meta-analysis of cohort studies 
reported that a $1 \%$ increase in hemoglobin $\mathrm{A}_{1} \mathrm{c}\left(\mathrm{HbA}_{1 \mathrm{c}}\right)$ in T2DM patients increased the risk of cardiovascular disease by 1.13-fold and stroke by 1.26-fold [7].

The risk of T2DM depends greatly on lifestyle [8], and decreased physical activity is a major factor in the development of T2DM [9]. A meta-analysis of epidemiological studies indicated that a sedentary lifestyle over a prolonged period increased the incidence of T2DM [10]. In order to alleviate T2DM, the American Diabetes Association (ADA) guidelines recommend engaging in exercise at moderate or greater intensity (i.e., $\geq 3.0$ metabolic equivalents [METs]; 3.0 METs is equivalent to walking $4.0 \mathrm{~km} / \mathrm{h}$ on a firm surface [11]) for $\geq 2.5$ hours per week [12]. Epidemiological studies reported a relationship between the incidence of cardiovascular disease and the exercise level in T2DM patients [13-18]. For example, a cohort study that followed Japanese T2DM patients for approximately 8 years reported that the risk of stroke decreased if the exercise level per week was $\geq 15.4$ METs $\times$ hour [13]. In addition, several systematic reviews and metaanalyses involving randomized controlled trials (RCTs) reported that exercise improved $\mathrm{HbA}_{1 \mathrm{c}}$ in T2DM patients [19-31], although there was heterogeneity in the improvement among the studies [19, 20, 22, 23, 25-27, 29, 30]. One of those meta-analyses reported that decreased $\mathrm{HbA}_{1 \mathrm{c}}$ was associated with high exercise levels [19]; thus, differences in exercise levels might be the reason for the heterogeneity. However, this meta-analysis was limited to RCTs involving only supervised aerobic exercise [19]. Types of exercise have become more varied [11], and systematic reviews and metaanalyses have evaluated the effects of various forms of exercise, including resistance training [22, 23], interval training [24], tai chi [27, 29, 30], yoga [28-30], and aquatic exercise [31], on $\mathrm{HbA}_{1 \mathrm{c}}$ in T2DM patients. No systematic review and meta-analysis have evaluated all types of exercise. We hypothesized that, in line with epidemiological studies [15-18], a meta-analysis of RCTs would indicate that $\mathrm{HbA}_{1 \mathrm{c}}$ improvement depends on the exercise level. In addition, previous systematic reviews [19-31] did not assess quality of individual RCTs or evidence overall and did not adequately discuss a form of exercise to improve $\mathrm{HbA}_{1 \mathrm{c}}$ and evidence for it.

Thus, the aim of the current systematic review and meta-analysis was to evaluate the relationship between changes in $\mathrm{HbA}_{1 \mathrm{c}}$ and the exercise level when performing various types of exercise in T2DM patients and assess quality of individual RCTs and evidence overall.

\section{Methods}

The current paper reported all 27 items that should be disclosed in a systematic review and meta-analysis as described in the Preferred Reporting Items for Systematic Reviews and Meta-analyses (PRISMA) statement [32] and was registered with the International Prospective Register of Systematic Reviews (PROSPERO, registration number: CRD42020181566) [33].

\subsection{Data Sources, Study Selection, and Data Extraction}

The current systematic review searched six electronic databases (MEDLINE via PubMed, EMBASE, Scopus, SPORTDiscus, CINAHL, and Cochrane library [CENTRAL]) with a combination of search terms related to diabetes mellitus, $\mathrm{HbA}_{1 \mathrm{c}}$, physical activity, exercise, and sports (Supplementary Material 1). In addition, a search of other sources was conducted by referring to articles cited in the current study and previous systematic reviews that reviewed the effect of exercise in T2DM patients. These searches were performed prior to August 31, 2020.

The inclusion criteria for RCTs were as follows: studies involving subjects with T2DM and a mean age of $\geq 18$ years; increased exercise performed by intervention group; no increase in exercise performed by control group; neither group received another intervention (e.g., diet and/or lifestyle change); study reported specifics of exercise (e.g., type, intensity, time [total exercise time per session], frequency [number of exercise sessions per week], and overall duration of intervention); study reported the mean $\mathrm{HbA}_{1 \mathrm{c}}$ and standard deviation (SD) or standard error of mean (SEM) at baseline 
and post-intervention for the intervention and control groups; and the overall duration of intervention was $\geq 12$ weeks (since $\mathrm{HbA}_{1 \mathrm{c}}$ indicates blood glucose levels over approximately that last 12 weeks [34]). The identified articles were first screened by title and abstract, and the full-text was obtained if the study included subjects with T2DM, intervention involving exercise, and reported $\mathrm{HbA}_{1 \mathrm{c}}$. The first and second authors determined whether the identified studies should be included in this systematic review. If they disagreed, the third author made the final decision regarding inclusion.

The current study was in accordance with the Cochrane data collection form for intervention review (RCTs only) [35]. The first and second authors independently extracted data (number of subjects, mean age, mean duration of diabetes, mean $\mathrm{HbA}_{1 \mathrm{C}}$, mean body mass index [BMI], and respective SDs or SEMs for the intervention and control groups) from each study in order to perform the meta-analysis. In addition, the type, intensity, time (min/session), frequency (sessions/week), and overall duration (weeks) of exercise were extracted as specifics of the intervention. METs in each study were estimated as the intensity of exercise. If studies indicated the percentage of maximal oxygen consumption (\% $\mathrm{O}_{2 \text { max }}$ ), percentage of heart rate reserve (\% HRR), percentage of maximal heart rate $\left(\% H R_{\max }\right)$, or Borg rating of perceived exertion (RPE), these values were converted to METs based on the characteristics and modalities of exercise [36]. If studies did not indicate the intensity, METs were estimated based on activity codes and the MET intensities defined by the American College of Sports Medicine (ACSM) [11].

\subsection{Risk of Bias}

The first and second authors used the version 2 of the Cochrane Collaboration tool to assess the risk of bias in each study [37]. This tool consists of six domains (bias arising from the randomization process generation, bias due to deviations from intended interventions, bias due to missing outcome data, bias in measurement of the outcome, bias in selection of the reported result, and overall bias). Each domain is ranked in one of three categories (low risk, some concerns, or high risk.).

\subsection{Data Synthesis}

The baseline and form of the exercise (intensity, time, frequency, and overall duration) data were expressed as the mean and SD, weighted by the number of subjects in each study.

The mean difference ([mean value at post-intervention in the exercise group - mean value at baseline in the exercise group] - [mean value at post-intervention in the control group - mean value at baseline in the control group]) was used as the effect size [38] and the mean difference in $\mathrm{HbA}_{1 \mathrm{c}}$ and $\mathrm{BMI}$ were calculated for each study. The weighted mean difference (WMD) was defined as the mean difference weighted by the inverse of the squared SEM of differences from baseline to post-intervention for each study; the current study pooled all WMDs as overall effects. The meta-analysis followed a random effects model in accordance with $\gamma=\theta+\varepsilon+\mu$ (Eq. 1), where $\gamma$ represents the effect size in each study, $\theta$ represents the true value, $\varepsilon$ represents the sampling error, and $\mu$ represents the between-study variance [39]. The pooled WMD was calculated using restricted maximum likelihood (REML) [40]. This approach is a random effects model that takes into account within-study and between-study variances as opposed to the fixed-effect model, which ignores between-study variance and which readily yields positive results. In comparison to the DerSimonian-Laird approach, which is typically used for random effects models, this method avoids underestimation errors [41].

In order to evaluate the relationship between the exercise level and changes in the $\mathrm{HbA}_{1 \mathrm{c}}$ and $\mathrm{BMI}$, we performed a multivariate meta-regression analysis, in which $\theta$ was replaced with $\beta_{0} x_{0}+\beta_{1} x_{1}$ (where $\beta$ represents the meta-regression coefficient and $x$ represents the explanatory variable]) in Eq. 1. Intensity (METs), time (min/session), frequency (sessions/week), and overall duration (weeks) of exercise were selected as $\mathrm{x}_{0}$ for the analysis. Furthermore, since a previous systematic review and meta-analysis reported that the baseline $\mathrm{HbA}_{1 \mathrm{c}}$ was inversely associated with changes in $\mathrm{HbA}_{1 \mathrm{c}}$ as a result of exercise [25], $\mathrm{x}_{1}$ was adjusted with the mean baseline $\mathrm{HbA}_{1 \mathrm{c}}$ in the current meta-regression analysis. 
The meta-regression equations were calculated, then $\mathrm{R}^{2}$ (the proportion of between-study variance explained by covariates) was calculated [42].

Sensitivity analyses were used to evaluate the influence of study characteristics and quality, and 7 categories (mean age $\geq 40$ years, mean baseline $\mathrm{HbA}_{1 \mathrm{c}} \geq 6.5 \%$, mean duration of $\mathrm{T} 2 \mathrm{DM} \geq 5.0$ years, mean baseline $\mathrm{BMI} \geq 30 \mathrm{~kg} / \mathrm{m}^{2}$, calculation of the WMD in BMI, performance of aerobic exercise alone, and no inclusion of a high risk of bias [37]) were defined. Once studies were limited to those falling into a given category, the pooled WMD in $\mathrm{HbA}_{1 \mathrm{c}}$ was calculated and meta-regression analyses were performed.

The mean difference, pooled WMD, and meta-regression coefficient were expressed with $95 \%$ confidence interval (CI). The heterogeneity of the pooled WMD as a result of variations among studies was assessed using Cochran's $Q$ statistic and $\mathrm{I}^{2}$ statistic. The $Q$ statistic was tested using the chi-squared test. P values of $<0.05$ were considered to indicate significant heterogeneity. In addition, the degree of heterogeneity was assessed in low $\left(I^{2}<25 \%\right)$, moderate $\left(I^{2}: 25-75 \%\right)$, and high $\left(I^{2}\right.$ $>75 \%)$ risk studies [43].

Publication bias was assessed using funnel plots consisting of the mean difference in the $\mathrm{HbA}_{1 \mathrm{c}}$ or $\mathrm{BMI}$ (x-axis) and the inverse of the SEM (y-axis). First, Egger's regression test was performed to evaluate the asymmetry of funnel plots [44], and $P$ values of $<0.05$ were considered to indicate a significant publication bias. Second, the trim and fill method of Duval and Tweedie was applied to estimate the number of missing studies and coordinates when they were located on a funnel plot [45]. If the results suggested that studies were missing, then the pooled WMDs in $\mathrm{HbA}_{1 \mathrm{c}}$ and BMI were adjusted by the addition of coordinates. The result was expressed as the WMD in light of the effect of these studies and the $95 \% \mathrm{Cl}$.

The current meta-analyses were performed using the JASP software program (Version 1.3; University of Amsterdam, Netherlands).

\subsection{The Certainty of Evidence}

The overall evidence was assessed using the Grading of Recommendations Assessment, Development and Evaluation (GRADE) approach [46]. The five domains (study limitations [risk of bias], inconsistency, indirectness, impression, and risk of publication bias) were ranked as one of the following: downgraded 2 levels (if very serious), downgraded 1 level (if serious), or not downgraded (if not serious); publication bias was downgraded 2 levels (if very likely), downgraded 1 level (if likely), or not downgraded (if not likely). The body of evidence was assessed as a high level of evidence (if not downgraded in any domain), a moderate level of evidence (if downgraded a total of 1 level), a low level of evidence (if downgraded 1 level in two domains, i.e., downgraded a total of 2 levels), or a very low level of evidence (if the aforementioned criteria were no met).

\section{Results}

\section{Study Characteristics and Risk of Bias}

The literature search yielded 304 studies. These studies involved subjects with T2DM, intervention in the form of exercise, and reported $\mathrm{HbA}_{1 \mathrm{c}}$ data. Among, these, 256 studies did not meet the selection criteria and were excluded. Finally, 48 studies were analyzed (Fig. 1) [47-94]. Table 1 shows a general description of the studies. The studies involved 2395 subjects (1514 subjects in exercise groups and 881 subjects in control groups). Table 2 shows baseline and form of exercise data.

Supplementary Material 2 shows the assessed risk of bias. Six studies $[49,54,63,74,79,86]$ had a high risk of bias in overall bias. 


\subsection{Data Synthesis}

Fig. 2 shows the baseline results and the forest plot of the mean difference from each study and the pooled WMD in $\mathrm{HbA}_{1 \mathrm{c}}$. The pooled WMD was significantly decreased but contained significant heterogeneity (moderate risk). The pooled WMD in BMI was calculated and evaluated with 35 studies reporting the mean BMI and its SD or SEM at baseline and post-intervention; the result decreased significantly $\left(-0.55 \mathrm{~kg} / \mathrm{m}^{2} ; 95 \% \mathrm{Cl},-0.58\right.$ to -0.51$)$ and did not contain heterogeneity $\left(\mathrm{Q}=25.8, \mathrm{P}=0.99 ; \mathrm{I}^{2}=0.0 \%\right.$; low risk). Table 3 shows the results of the sensitivity analyses of $\mathrm{HbA}_{1 \mathrm{c}}$. When studies were limited to those in a given category, there was a significant decrease in all pooled WMDs in $\mathrm{HbA}_{1 \mathrm{c}}$ and the WMDs contained significant heterogeneity (moderate risk); that is, there was no change in the results.

Tables 4 and 5 show the results of a meta-regression analysis of the relationship between exercise level and WMD in $\mathrm{HbA}_{1 \mathrm{c}}$; here, the WMD in $\mathrm{HbA}_{1 \mathrm{c}}$ was adjusted by the mean baseline $\mathrm{HbA}_{1 \mathrm{c}}$. All meta-regression coefficients of the mean baseline $\mathrm{HbA}_{1 \mathrm{c}}$ were $<0.00$, and the meta-regression coefficient was significantly associated with the WMD in $\mathrm{HbA}_{1 \mathrm{c}}$. The

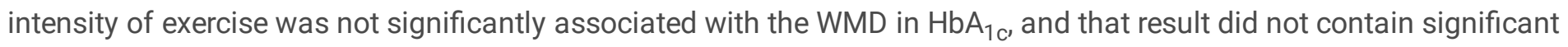
heterogeneity. The time and frequency of exercise were not significantly associated with the WMD in $\mathrm{HbA}_{1}$; these results did not contain significant heterogeneity. However, the overall duration of exercise was significantly associated with the WMD in $\mathrm{HbA}_{1 \mathrm{c}}$, and those results did not contain significant heterogeneity. Sensitivity analyses indicated no change in that relationship in any.

Supplementary Material 3 shows the results of a meta-regression analysis of the relationship between the exercise level and WMD in BMl; here, the WMD in BMI was adjusted by the mean baseline $\mathrm{HbA}_{1 \mathrm{c}}$. The intensity, time, frequency, and overall duration of exercise were not significantly associated with the WMD in BMI.

Supplementary Material 4 and 5 show funnel plots for publication bias with regard to $\mathrm{HbA}_{1 \mathrm{c}}$ and $\mathrm{BMI}$, respectively. Egger's regression test showed no significant asymmetry in $\mathrm{HbA}_{1 \mathrm{c}}$ and $\mathrm{BMI}(\mathrm{P}=0.31$ and $\mathrm{P}=0.35$, respectively). Duval and Tweedie's trim and fill method suggested that four studies were missing $\mathrm{HbA}_{1 \mathrm{c}}$ data and eight studies were missing $\mathrm{BMI}$ data. After adjusting for the effects of these missing studies, the pooled WMD in $\mathrm{HbA}_{1 \mathrm{c}}$ was estimated to be $-0.5 \%(95 \%$ $\mathrm{Cl},-0.6$ to $-0.4 ; \mathrm{Q}=119.0, \mathrm{P}<0.05$ for heterogeneity, $\left.\mathrm{I}^{2}=39.5 \%\right)$, and the pooled WMD in $\mathrm{BMI}$ was estimated to be -0.55 $\mathrm{kg} / \mathrm{m}^{2}\left(95 \% \mathrm{Cl},-0.59\right.$ to $-0.51 ; \mathrm{Q}=32.7, \mathrm{P}>0.05$ for heterogeneity, $\left.\mathrm{I}^{2}=0.0 \%\right)$.

\subsection{The Certainty of Evidence}

The study limitations (risk of bias) domain was ranked as serious, but there were no serious concerns in other domains (the inconsistency, indirectness, impression, and publication of bias). Thus, there was a moderate level of evidence for a decrease in $\mathrm{HbA}_{1 \mathrm{c}}$ as a result of exercise.

\section{Discussion}

This systematic review and meta-analysis were conducted to evaluate the effect of exercise on $\mathrm{HbA}_{1 \mathrm{c}}$ in $\mathrm{T} 2 \mathrm{DM}$ patients. The results indicated a decrease in $\mathrm{HbA}_{1 \mathrm{c}}$; however, the effect contained heterogeneity. In addition, results of metaregression analyses indicated that changes in $\mathrm{HbA}_{1 \mathrm{c}}$ were associated with the overall duration of exercise (weeks) but not the intensity (METs), time (min/session), or frequency (sessions/week) of exercise.

\subsection{Comparison with Other Studies}

Several previous meta-analyses reported a decrease in $\mathrm{HbA}_{1 \mathrm{c}}$ as a result of exercise [19-31]. However, the meta-analyses involved aerobic exercise or resistance training alone and the observed effects contained heterogeneity $[19,20,22,23,30]$, 
indicating that the effect on $\mathrm{HbA}_{1 \mathrm{c}}$ differed among RCTs even if those RCTs were limited to studies involving the same type of exercise. The current study assumed that the effect on $\mathrm{HbA}_{1 \mathrm{c}}$ was affected by the exercise level. Results of analyses indicated that the intensity, time, and frequency of exercise were not associated with changes in $\mathrm{HbA}_{1 \mathrm{c}}$, and those results were similar to the results of an analysis limited to RCTs involving aerobic exercise. Thus, differences due to the type of exercise presumably have no effect on improvement of $\mathrm{HbA}_{1 \mathrm{c}}$. Notably, a meta-analysis that evaluated the percentage of T2DM patients who dropped out from an exercise intervention reported that a protocol involving vigorous exercise resulted in a higher percentage of drop-outs in comparison to moderate intensity exercise [94]. Given that a difference in intensity of exercise did not affect the improvement in $\mathrm{HbA}_{1 \mathrm{c}}$, T2DM patients should probably perform exercise at low to moderate intensity. In fact, meta-analyses of studies involving low to moderate intensity exercise, such as walking [20,30], yoga [30], or tai chi [27], reported that these types of exercise were associated with $\mathrm{HbA}_{1 \mathrm{c}}$ improvement.

Since the current study indicated that changes in $\mathrm{HbA}_{1 \mathrm{c}}$ were associated with the overall duration of exercise and that heterogeneity in the changes improved, the overall duration of exercise may depend on changes in $\mathrm{HbA}_{1 \mathrm{c}}$ and it may be a cause of that heterogeneity. However, these findings indicate that $\mathrm{HbA}_{1 \mathrm{c}}$ increases rather than decrease as a result of continuing exercise. Therefore, exercise may not necessarily be beneficial for patients with T2DM. One reason for this is that all of the RCTs analyzed in this meta-analysis involved an exercise intervention alone (without diet, medication, or lifestyle modifications). Although in the minority, a previous meta-analysis reported that $\mathrm{HbA}_{1 \mathrm{c}}$ decreased as a result of a combination of diet and exercise recommendations but was not by the recommendation of exercise alone [26]. Thus, $\mathrm{HbA}_{1 \mathrm{c}}$ may not necessarily tend to decrease in T2DM patients, if they perform exercise alone for a long duration. A recent meta-analysis on nutrition reported that $\mathrm{HbA}_{1 \mathrm{c}}$ and $\mathrm{BMI}$ improved in the short term following intervention in the form of a low-carbohydrate diet alone; however, these effects were not sustained over the long term [96]. Thus, previous studies and the current study only indicated the effect of intervention in the form of nutrition or exercise alone, instead of evaluating the effects of multiple interventions. A meta-analysis of RCTs involving subjects without T2DM reported that exercise and diet significantly decreased the incidence of T2DM while exercise alone or diet alone did not [97]. Thus, intervention combining exercise and diet may be essential to alleviate T2DM. A recent meta-analysis of cohort studies found that the combination of exercise and diet should be emphasized for T2DM patients [18]. RCTs and/or meta-analyses of multiple interventions should be conducted in the future.

\subsection{Mechanisms}

The mechanisms responsible for the alleviation of T2DM by exercise have been attributed to several physiological processes [98]. Several epidemiological studies reported that BMI was associated with insulin resistance [99, 100]; the current study indicated that BMI was significantly decreased as a result of exercise but that the effect did not contain significant heterogeneity; changes in BMI were not significantly associated with the exercise level. Thus, a decrease in $\mathrm{HbA}_{1 \mathrm{c}}$ may differ from changes in BMI. In addition, adipocytokines dramatically affect the action of insulin. A previous meta-analysis of RCTs involving T2DM patients examined the effects of exercise on adipocytokines; the results indicated improvements in leptin and interleukin- 6 but no change in adiponectin [101]. Interleukin-6 is considered to a factor associated with enhanced insulin secretion [102]; thus improvement in interleukin- 6 as a result of exercise may cause a decrease in $\mathrm{HbA}_{1 \mathrm{c}}$. However, few studies have evaluated adipocytokines [56, 57, 59, 60, 84], a fact that became apparent from the RCTs analyzed in the current study. Furthermore, the mechanisms underlying the lack of decrease in $\mathrm{HbA}_{1 \mathrm{c}}$ after continued exercise, a finding from the current study, are unclear. Although a stand-alone finding, a systematic review suggested that continued exercise inhibited the gastrointestinal function and depressed the immune system in healthy individuals [103]. Excessive exercise may have some effect on the immune system and/or glucose metabolism. The underlying mechanisms should be investigated in the future. 
One strength of the current meta-analysis is that it attempted to account for the effects of confounding factors in order to indicate the relationship between the exercise level and $\mathrm{HbA}_{1 \mathrm{c}}$. Subject characteristics (age, state of blood glucose levels at baseline, duration of T2DM, and overweight) and the form of exercise (aerobic exercise alone) were considered in sensitivity analyses, and the results did not change even when analyses were limited to certain RCTs. Furthermore, the change in $\mathrm{HbA}_{1 \mathrm{c}}$ was adjusted based on the mean baseline level in the current meta-regression analyses; thus, the influence of the aforementioned factors was presumably minimized. In addition, previous studies [19-31] did not assess the quality of each RCT using the version 2 of the risk of bias tool [37] and/or evidence overall using the GRADE approach [46], so evidence of the effects of exercise on $\mathrm{HbA} 1 \mathrm{c}$ in T2DM patients may have been insufficient. The use of these assessments in the current study is presumably another one of its strengths. Nevertheless, approximately $10 \%$ of the RCTs analyzed in the current study included a high risk of bias and in particular had issues in terms of the random allocation process and/or missing outcome data, so this study had limitations. The influence of this bias contributed to a moderate level of evidence overall according to the GRADE approach. When studies were limited to those not including a high risk of bias in sensitivity analyses, heterogeneity did not change as a result of exercise. However, these issues with the intervention need to be considered and addressed in the future.

Another limitation of this study is that findings did not provide sufficient evidence of the effect of exercise over a prolonged period. All RCTs analyzed in this systematic review and meta-analysis involved an intervention for $\leq 1$ year; thus, a systematic review and meta-analysis of RCTs involving an exercise intervention for $\geq 1$ year should be conducted.

\section{Conclusions}

In conclusion, the current results indicated that $\mathrm{HbA}_{1 \mathrm{c}}$ decreased as result of intervention of exercise in T2DM patients; however, the changes in $\mathrm{HbA}_{1 \mathrm{c}}$ were associated with the overall duration of exercise. Therefore, continuing exercise may not necessarily be beneficial for patients with T2DM. This may be the result of intervention in the form of exercise alone.

\section{Declarations}

\section{Acknowledgment}

The authors wish to sincerely thank the staff of Osaka City University Media Center Library Service for collecting the articles used in this analysis and to thank the staff of Toin University of Yokohama Library, National Museum of Ethnology, and National Institute of Public Health for facilitating a search of the literature in electronic databases.

\section{Data Availability Statement}

All data are available in submitted manuscript or as electronic supplementary material.

\section{Funding}

No sources of funding were used to assist in the preparation of this article.

\section{Conflict of interest}

Conflict of interest Yutaka Igarashi, Nobuhiko Akazawa, and Seiji Maeda have no conflicts of interest relevant to the content of this article.

\section{References}


1. International Diabetes Federation (2019) IDF Diabetes Atlas 9th ed. Available from https://www.diabetesatlas.org. Accessed 31 December 2020

2. Fujishima M, Kiyohara Y, Kato I, Ohmura T, Iwamoto H, Nakayama K, et al. Diabetes and cardiovascular disease in a prospective population survey in Japan: The Hisayama Study. Diabetes. 1996;45(Suppl 3):S14-6.

3. Stratton IM, Adler Al, Neil HA, Matthews DR, Manley SE, Cull CA, et al. Association of glycaemia with macrovascular and microvascular complications of type 2 diabetes (UKPDS 35): prospective observational study. BMJ. 2000;321:405-412.

4. Wright AK, Kontopantelis E, Emsley R, Buchan I, Mamas MA, Sattar N, et al. Cardiovascular risk and risk factor management in type 2 diabetes mellitus. Circulation. 2019;139(24):2742-53.

5. Currie CJ, Peters JR, Tynan A, Evans M, Heine RJ, Bracco OL, et al. Survival as a function of HbA(1c) in people with type 2 diabetes: a retrospective cohort study. Lancet. 2010;375(9713):481-9.

6. Chiang JI, Hanlon P, Li TC, Jani BD, Manski-Nankervis JA, Furler J, et al. Multimorbidity, mortality, and HbA1c in type 2 diabetes: A cohort study with UK and Taiwanese cohorts. PLoS Med. 2020;17(5):e1003094.

7. Selvin E, Marinopoulos S, Berkenblit G, Rami T, Brancati FL, Powe NR, et al. Meta-analysis: glycosylated hemoglobin and cardiovascular disease in diabetes mellitus. Ann Intern Med. 2004;141(6):421-31.

8. Shan Z, Li Y, Zong G, Guo Y, Li J, Manson JE, et al. Rotating night shift work and adherence to unhealthy lifestyle in predicting risk of type 2 diabetes: results from two large US cohorts of female nurses. BMJ. 2018;363:k4641.

9. Honda T, Kishimoto H, Mukai N, Hata J, Yoshida D, Hirakawa Y, et al. Objectively measured sedentary time and diabetes mellitus in a general Japanese population: The Hisayama Study. J Diabetes Investig. 2019;10(3):809-16.

10. Wilmot EG, Edwardson CL, Achana FA, Davies MJ, Gorely T, Gray LJ, et al. Sedentary time in adults and the association with diabetes, cardiovascular disease and death: systematic review and meta-analysis. Diabetologia. 2012;55(11):2895-2905.

11. Ainsworth BE, Haskell WL, Whitt MC, Irwin ML, Swartz AM, Strath SJ, et al. Compendium of physical activities: an update of activity codes and MET intensities. Med Sci Sports Exerc. 2000;32(9 Suppl):S498-S504.

12. American Diabetes Association. Standards of Medical Care in Diabetes-2019 Abridged for Primary Care Providers. Clin Diabetes. 2019;37(1):11-34.

13. Sone H, Tanaka S, Tanaka S, Suzuki S, Seino H, Hanyu O, et al. Leisure-time physical activity is a significant predictor of stroke and total mortality in Japanese patients with type 2 diabetes: analysis from the Japan Diabetes Complications Study (JDCS). Diabetologia. 2013;56(5):1021-30.

14. Okada K, Hayashi T, Tsumura K, Suematsu C, Endo G, Fujii S. Leisure-time physical activity at weekends and the risk of type 2 diabetes mellitus in Japanese men: the Osaka Health Survey. Diabet Med. 2000;17(1):53-8.

15. Manson JE, Rimm EB, Stampfer MJ, Colditz GA, Willett WC, Krolewski AS, et al. Physical activity and incidence of non-insulin-dependent diabetes mellitus in women. Lancet. 1991;338(8770):774-8.

16. Manson JE, Nathan DM, Krolewski AS, Stampfer MJ, Willett WC, Hennekens CH. A prospective study of exercise and incidence of diabetes among US male physicians. JAMA. 1992;268(1):63-7.

17. Huai P, Han H, Reilly KH, Guo X, Zhang J, Xu A. Leisure-time physical activity and risk of type 2 diabetes: a metaanalysis of prospective cohort studies. Endocrine. 2016;52(2):226-30.

18. Zhang Y, Pan XF, Chen J, Xia L, Cao A, Zhang Y, et al. Combined lifestyle factors and risk of incident type 2 diabetes and prognosis among individuals with type 2 diabetes: a systematic review and meta-analysis of prospective cohort studies. Diabetologia. 2020;63(1):21-33.

19. Delevatti RS, Bracht CG, Lisboa SDC, Costa RR, Marson EC, Netto N, et al. The role of aerobic training variables progression on glycemic control of patients with type 2 diabetes: a systematic review with meta-analysis. Sports Med Open. 2019;5(1):22. 
20. Qiu S, Cai X, Schumann U, Velders M, Sun Z, Steinacker JM. Impact of walking on glycemic control and other cardiovascular risk factors in type 2 diabetes: a meta-analysis. PLoS One. 2014;9(10):e109767.

21. Qiu S, Cai X, Chen X, Yang B, Sun Z. Step counter use in type 2 diabetes: a meta-analysis of randomized controlled trials. BMC Med. 2014;12:36.

22. Liu Y, Ye W, Chen Q, Zhang Y, Kuo CH, Korivi M. Resistance exercise intensity is correlated with attenuation of HbA1c and insulin in patients with type 2 diabetes: A systematic review and meta-analysis. Int J Environ Res Public Health. 2019;16(1):140.

23. Acosta-Manzano P, Rodriguez-Ayllon M, Acosta FM, Niederseer D, Niebauer J. Beyond general resistance training. Hypertrophy versus muscular endurance training as therapeutic interventions in adults with type 2 diabetes mellitus: A systematic review and meta-analysis. Obes Rev. 2020;21(6):e13007.

24. Liu JX, Zhu L, Li PJ, Li N, Xu YB. Effectiveness of high-intensity interval training on glycemic control and cardiorespiratory fitness in patients with type 2 diabetes: a systematic review and meta-analysis. Aging Clin Exp. Res 2019;31(5):575-93.

25. Umpierre D, Ribeiro PA, Schaan BD, Ribeiro JP. Volume of supervised exercise training impacts glycaemic control in patients with type 2 diabetes: a systematic review with meta-regression analysis. Diabetologia. 2013;56(2):242-51.

26. Umpierre D, Ribeiro PA, Kramer CK, Leitão CB, Zucatti AT, Azevedo MJ, et al. Physical activity advice only or structured exercise training and association with $\mathrm{HbA} 1 \mathrm{c}$ levels in type 2 diabetes: a systematic review and meta-analysis. JAMA. 2011;305(17):1790-9.

27. Chao M, Wang C, Dong X, Ding M. The effects of tai chi on type 2 diabetes mellitus: a meta-analysis. J Diabetes Res. 2018;2018:7350567.

28. Ramamoorthi R, Gahreman D, Skinner T, Moss S. The effect of yoga practice on glycemic control and other health parameters in the prediabetic state: A systematic review and meta-analysis. PLoS One. 2019;14(10):e0221067.

29. Xia T, Yang Y, Li W, Tang Z, Huang Q, Li Z, et al. Meditative movements for patients with type 2 diabetes: a systematic review and meta-analysis. Evid Based Complement Alternat Med. 2020;2020:5745013.

30. Pai LW, Li TC, Hwu YJ, Chang SC, Chen LL, Chang PY. The effectiveness of regular leisure-time physical activities on long-term glycemic control in people with type 2 diabetes: A systematic review and meta-analysis. Diabetes Res Clin Pract. 2016;113:77-85.

31. Rees JL, Johnson ST, Boulé NG. Aquatic exercise for adults with type 2 diabetes: a meta-analysis. Acta Diabetol. 2017;54(10):895-904.

32. Shamseer L, Moher D, Clarke M, Ghersi D, Liberati A, Petticrew M, et al. Preferred reporting items for systematic review and meta-analysis protocols (PRISMA-P) 2015: elaboration and explanation. BMJ. 2015;350:g7647.

33. University of York, Centre for reviews and dissemination (2011) PROSPERO: international prospective register of systematic reviews. Available from https://www.crd.york.ac.uk/prospero. Accessed 31 December 2020

34. American Diabetes Association. 6. Glycemic targets: Standards of medical care in diabetes-2020. Diabetes Care. 2020;43(Suppl. 1):S66-S76.

35. Cochrane Skin Group (2014) Data collection forms for intervention reviews: RCTs only, version 3. Available from https://skin.cochrane.org/resources. Accessed 31 December 2020.

36. Vanhees L, Geladas N, Hansen D, Kouidi E, Niebauer J, Reiner Z, et al. Importance of characteristics and modalities of physical activity and exercise in the management of cardiovascular health in individuals with cardiovascular risk factors: recommendations from the EACPR. Part II. Eur J Prev Cardiol. 2012;19(5):1005-33.

37. Sterne JAC, Savović, J, Page MJ, Elbers RG, Blencowe NS, Boutron I, et al. RoB 2: a revised tool for assessing risk of bias in randomised trials. BMJ. 2019;366: 14898. 
38. Igarashi Y, Nogami Y. Running to lower resting blood pressure: a systematic review and meta-analysis. Sports Med. 2020;50(3):531-41.

39. Harbord RM, Higgins JPT. Meta-regression in Stata. Stata J. 2008;8:493-519.

40. Hardy RJ, Thompson SG. A likelihood approach to meta-analysis with random effects. Stat Med. 1996;15(6):619-29.

41. Langan D, Higgins JPT, Jackson D, Bowden J, Veroniki AA, Kontopantelis E, et al. A comparison of heterogeneity variance estimators in simulated random-effects meta-analyses. Res Synth Methods. 2019;10(1):83-98.

42. Aloe AM, Becker BJ, Pigott TD. An alternative to R(2) for assessing linear models of effect size. Res Synth Methods. 2010;1(3-4):272-83.

43. Higgins JP, Thompson SG, Deeks JJ, Altman DG. Measuring inconsistency in meta-analyses. BMJ. 2003;327(7414):557-60.

44. Egger M, Davey Smith G, Schneider M, Minder C. Bias in meta-analysis detected by a simple, graphical test. BMJ. 1997;315(7109):629-34.

45. Duval S, Tweedie R. Trim and fill: a simple funnel-plot-based method of testing and adjusting for publication bias in meta-analysis. Biometrics. 2000;56(2):455-63.

46. Guyatt GH, Oxman AD, Kunz R, Vist GE, Falck-Ytter Y, Schünemann HJ; GRADE Working Group. What is "quality of evidence" and why is it important to clinicians? BMJ. 2015;336:995-8.

47. Rönnemaa T, Mattila K, Lehtonen A, Kallio V. A controlled randomized study on the effect of long-term physical exercise on the metabolic control in type 2 diabetic patients. Acta Med Scand.1986;220(3):219-24.

48. Verity LS, Ismail AH. Effects of exercise on cardiovascular disease risk in women with NIDDM. Diabetes Res Clin Pract.1989;6(1):27-35.

49. Raz I, Hauser E, Bursztyn M. Moderate exercise improves glucose metabolism in uncontrolled elderly patients with non-insulin-dependent diabetes mellitus. Isr J Med Sci.1994;30(10):766-70.

50. Tessier D, Ménard J, Fülöp T, Ardilouze J, Roy M, Dubuc N, et al. Effects of aerobic physical exercise in the elderly with type 2 diabetes mellitus. Arch Gerontol Geriatr. 2000;31(2):121-32.

51. Tsujiuchi T, Kumano H, Yoshiuchi K, He D, Tsujiuchi Y, Kuboki T, et al. The Effect of qi-gong relaxation exercise on the control of type 2 diabetes mellitus: A randomized controlled trial. Diabetes Care. 2002;25(1):241-2.

52. Cuff DJ, Meneilly GS, Martin A, Ignaszewski A, Tildesley HD, Frohlich JJ. Effective exercise modality to reduce insulin resistance in women with type 2 diabetes. Diabetes Care.2003;26(11):2977-82.

53. Loimaala A, Huikuri HV, Kööbi T, Rinne M, Nenonen A, Vuori I. Exercise training improves baroreflex sensitivity in type 2 diabetes. Diabetes. 2003;52(7):1837-1842.

54. Dela F, von Linstow ME, Mikines KJ, Galbo H. Physical training may enhance beta-cell function in type 2 diabetes. Am J Physiol Endocrinol Metab. 2004;287(5):E1024-31

55. Bjørgaas M, Vik JT, Saeterhaug A, Langlo L, Sakshaug T, Mohus RM, et al. Relationship between pedometer-registered activity, aerobic capacity and self-reported activity and fitness in patients with type 2 diabetes. Diabetes Obes Metab. 2005;7(6):737-44.

56. Brooks N, Layne JE, Gordon PL, Roubenoff R, Nelson ME, Castaneda-Sceppa C. Strength training improves muscle quality and insulin sensitivity in Hispanic older adults with type 2 diabetes. Int J Med Sci. 2006;18;4(1):19-27.

57. Gordon PL, Vannier E, Hamada K, Layne J, Hurley BF, Roubenoff R, et al. Resistance training alters cytokine gene expression in skeletal muscle of adults with type 2 diabetes. Int J Immunopathol Pharmacol.2006;19(4):739-49.

58. Middlebrooke AR, Elston LM, Macleod KM, Mawson DM, Ball Cl, Shore AC, et al. Six months of aerobic exercise does not improve microvascular function in type 2 diabetes mellitus. Diabetologia.2006;49(10):2263-71.

59. Kadoglou NP, Iliadis F, Angelopoulou N, Perrea D, Ampatzidis G, Liapis CD, et al. The anti-inflammatory effects of exercise training in patients with type 2 diabetes mellitus. Eur J Cardiovasc Prev Rehabil. 2007;14(6):837-43. 
60. Lam P, Dennis SM, Diamond TH, Zwar N. Improving glycaemicand BP controlin type 2 diabetes.

The effectiveness of tai chi. Aust Fam Physician. 2008;37(10):884-7.

61. Lambers S, Van Laethem C, Van Acker K, Calders P. Influence of combined exercise training on indices of obesity, diabetes and cardiovascular risk in type 2 diabetes patients. Clin Rehabil.2008;22(6):483-92.

62. Ribeiro IC, Iborra RT, Neves MQ, Lottenberg SA, Charf AM, Nunes VS, et al. HDL atheroprotectionby a erobic exercise trainingin type 2 diabetes mellitus. Med Sci Sports Exerc. 2008;40:779-86.

63. Murrock CJ, Higgins PA, Killion C. Dance and peer support to improve diabetes outcomes in African American women. Diabetes Educ. 2009;35(6):995-1003.

64. Shenoy S, Arora E, Jaspal S. Effects of progressive resistance training and aerobic exercise on type 2 diabetics in Indian population. Int J Diabetes Metab. 2009;17:27-30.

65. Church TS, Blair SN, Cocreham S, Johannsen N, Johnson W, Kramer K, et al. Effects of aerobic and resistance training on hemoglobin A1c levels in patients with type 2 diabetes: a randomized controlled trial JAMA. 2010;304(20):2253-62.

66. Hosaka Y, Nagasaki M, Bajotto G, Shinomiya Y, Ozawa T, Sato Y. Effects of daily mechanical horseback riding on insulin sensitivity and resting metabolism in middle-aged type 2 diabetes mellitus patients. Nagoya J Med Sci. 2010;72(3-4):129-37.

67. Plotnikoff RC, Eves N, Jung M, Sigal RJ, Padwal R, Karunamuni N. Multicomponent, home-based resistance training for obese adults with type 2 diabetes: a randomized controlled trial. Int J Obes (Lond). 2010;34(12):1733-41.

68. Reid RD, Tulloch HE, Sigal RJ, Kenny GP, Fortier M, McDonnell L, et al. Effects of aerobic exercise, resistance exercise or both, on patient-reported health status and well-being in type 2 diabetes mellitus: a randomised trial. Diabetologia. 2010;53(4):632-40.

69. Sun GC, Lovejoy JC, Gillham S, Putiri A, Sasagawa M, Bradley R. Effectsof Qigongon glucose control in type 2 diabetes: a randomized controlled pilot study. Diabetes Care. 2010;33(1):e8.

70. Yavari A, Hajiyev AM, Naghizadeh F. The effect of aerobic exercise on glycosylated hemoglobin values in type 2 diabetes patients. J Sports Med Phys Fitness. 2010;50(4):501-5.

71. Belli T, Ribeiro LF, Ackermann MA, Baldissera V, Gobatto CA, Galdino da Silva R. Effects of 12-week overground walking training at ventilatory threshold velocity in type 2 diabetic women. Diabetes Res Clin Pract. 2011;93(3):33743.

72. Kurban S, Mehmetoglu I, Yerlikaya HF, Gönen S, Erdem S. Effect of chronic regular exercise on serum ischemiamodified albumin levels and oxidative stress in type 2 diabetes mellitus. Endocr Res. 2011;36(3):116-23.

73. Kwon HR, Min KW, Ahn HJ, Seok HG, Lee JH, Park GS, et al. Effects of aerobic exercise vs. resistance training on endothelial function in women with type 2 diabetes mellitus. Diabetes Metab J. 2011;35(4):364-73.

74. de Oliveira VN, Bessa A, Jorge ML, Oliveira RJ, de Mello MT, De Agostini GG, et al. The effect of different training programs on antioxidant status, oxidative stress, and metabolic control in type 2 diabetes. Appl Physiol Nutr Metab. Appl Physiol Nutr Metab. 2012;37(2):334-44.

75. Nuttamonwarakul A, Amatyakul S, Suksom D. Twelve weeks of aqua-aerobic exercise improve health-related physical fitness and glycemic control in elderly patients with type 2 diabetes. J Exerc Physiol Online. 2012;15(2):64-70.

76. Swift DL, Johannsen NM, Earnest CP, Blair SN, Church TS. Effect of exercise training modality on C-reactive protein in type 2 diabetes. Med Sci Sports Exerc. 2012;44(6):1028-34.

77. Tan S, Li W, Wang J. Effects of six months of combined aerobic and resistance training for elderly patients with a long history of type 2 diabetes. J Sports Sci Med. 2012;11(3):495-501.

78. Fritz T, Caidahl K, Krook A, Lundström P, Mashili F, Osler M, et al. Effects of Nordic walking on cardiovascular risk factors in overweight individuals with type 2 diabetes, impaired or normal glucose tolerance. Diabetes Metab Res 
Rev. 2013;29(1):25-32.

79. Karstoft K, Winding K, Knudsen SH, Nielsen JS, Thomsen C, Pedersen BK, et al. The effects of free-living intervalwalking training on glycemic control, body composition, and physical fitness in type 2 diabetic patients: a randomized, controlled trial. Diabetes Care. 2013;36(2):228-36.

80. Sparks LM, Johannsen NM, Church TS, Earnest CP, Moonen-Kornips E, Moro C, et al. Nine months of combined training improves ex vivo skeletal muscle metabolism in individuals with type 2 diabetes. J Clin Endocrinol Metab. 2013;98(4):1694-1702.

81. Youngwanichsetha S, Phumdoung S, Ingkathawornwong T. The effects of tai chi qigong exercise on plasma glucose levels and health status of postpartum Thai women with type 2 diabetes. Focus Altern Complement Ther. 2013;18(4):182-7.

82. Mitranun W, Deerochanawong C, Tanaka H, Suksom D. Continuous vs interval training on glycemic control and macro- and microvascular reactivity in type 2 diabetic patients. Scand J Med Sci Sports. 2014;24:e69-76.

83. Yan H, Prista A, Ranadive SM, Damasceno A, Caupers P, Kanaley JA, et al. Effect of aerobic training on glucose control and blood pressure in T2DDM East African males. ISRN Endocrinol. 2014;2014:864897.

84. Dede ND, İpekci SH, Kebapcılar L, Arslan M, Kurban S, Yıldız M, et al. Influence of exercise on leptin, adiponectin and quality of life in type 2 diabetics. Turk J Endocrinol Metab. 2015;19(1):7-13.

85. Lee SF, Pei D, Chi MJ, Jeng C. An investigation and comparison of the effectiveness of different exercise programmes in improving glucose metabolism and pancreatic $\beta$ cell function of type 2 diabetes patients. Int J Clin Pract. 2015;69(10):1159-70.

86. Park SY, Lee IH. Effects on training and detraining on physical function, control of diabetes and anthropometrics in type 2 diabetes; a randomized controlled trial. Physiother Theory Pract. 2015;31(2):83-8.

87. Xiao CM, Zhuang YC. Effects of Tai Chi ball on balance and physical function in older adults with type 2 diabetes mellitus. J Am Geriatr Soc. 2015;63(1):176-7.

88. Cassidy S, Thoma C, Hallsworth K, Parikh J, Hollingsworth KG, Taylor R, et al. High intensity intermittent exercise improves cardiac structure and function and reduces liver fat in patients with type 2 diabetes: a randomised controlled trial. Diabetologia. 2016;59(1):56-66.

89. Keshavarz S, Eslahchi N, Pourhakimi E, Karimi M. Effect of high- fiber diet alongside with aerobic exercise on HbA1c, fasting blood glucose and BMI of overweight diabetic women. Report of Health Care J. 2016;2(2):60-8.

90. Tomas-Carus P, Ortega-Alonso A, Pietilainen KH, Santos V, Goncalves H, Ramos J, et al. A randomized controlled trial on the effects of combined aerobic-resistance exercise on muscle strength and fatigue, glycemic control and healthrelated quality of life of type 2 diabetes patients. J Sports Med Phys Fitness. 2016;56(5):572-8.

91. Annibalini G, Lucertini F, Agostini D, Vallorani L, Gioacchini A, Barbieri E, et al. Concurrent aerobic and resistance training has anti-inflammatory effects and increases both plasma and leukocyte levels of IGF-1 in late middle-aged type 2 diabetic patients. Oxid Med Cell Longev. 2017;2017:3937842.

92. Botton CE, Umpierre D, Rech A, Pfeifer LO, Machado CLF, Teodoro JL, et al. Effects of resistance training on neuromuscular parameters in elderly with type 2 diabetes mellitus: a randomized clinical trial. Exp Gerontol. 2018;113:141-9.

93. Hsieh PL, Tseng CH, Tseng YJ, Yang WS. Resistance training improves muscle function and cardiometabolic risks but not quality of life in older people with type 2 diabetes mellitus: A randomized controlled trial. J Geriatr Phys Ther. 2018;41(2):65-76.

94. Stubbs EB Jr, Fisher MA, Miller CM, Jelinek C, Butler J, McBurney C, et al. Randomized controlled trial of physical exercise in diabetic veterans with length-dependent distal symmetric polyneuropathy. Front Neurosci. 2019;13:51. 
95. Jabardo-Camprubí G, Donat-Roca R, Sitjà-Rabert M, Milà-Villarroel R, Bort-Roig J. Drop-out ratio between moderate to high-intensity physical exercise treatment by patients with, or at risk of, type 2 diabetes mellitus: A systematic review and meta-analysis. Physiol Behav. 2020;215:112786.

96. Silverii GA, Botarelli L, Dicembrini I, Girolamo V, Santagiuliana F, Monami M, et al. Low-carbohydrate diets and type 2 diabetes treatment: a meta-analysis of randomized controlled trials. Acta Diabetol. 2020;57(11):1375-82.

97. Orozco LJ, Buchleitner AM, Gimenez-Perez G, Figuls MRI, Richter B, Mauricio D. Exercise or exercise and diet for preventing type 2 diabetes mellitus. Cochrane Database Syst Rev. Cochrane Database Syst Rev. 2008;(3):CD003054.

98. Stanford KI, Goodyear LJ. Exercise and type 2 diabetes: molecular mechanisms regulating glucose uptake in skeletal muscle. Adv Physiol Educ. 2014;38(4):308-14.

99. Ohnishi H, Saitoh S, Takagi S, Ohata J, Takeuchi H, Isobe T, et al. Incidence of insulin resistance in obese subjects in a rural Japanese population: the Tanno and Sobetsu study. Diabetes Obes Metab. 2005;7(1):83-7.

100. Okura T, Nakamura R, Fujioka Y, Kawamoto-Kitao S, Ito $Y$, Matsumoto $K$, et al. Body mass index $\geq 23$ is a risk factor for insulin resistance and diabetes in Japanese people: A brief report. PLoS One. 2018;13(7):e0201052.

101. Hayashino Y, Jackson JL, Hirata T, Fukumori N, Nakamura F, Fukuhara S, et al. Effects of exercise on C-reactive protein, inflammatory cytokine and adipokine in patients with type 2 diabetes: a meta-analysis of randomized controlled trials. Metabolism. 2014;63(3):431-40.

102. Suzuki T, Imai J, Yamada T, Ishigaki Y, Kaneko K, Uno K, et al. Interleukin-6 enhances glucose-stimulated insulin secretion from pancreatic beta-cells: potential involvement of the PLC-IP3-dependent pathway. Diabetes. 2011;60(2):537-47.

103. Costa RJS, Snipe RMJ, Kitic CM, Gibson PR. Systematic review: exercise-induced gastrointestinal syndromeimplications for health and intestinal disease. Aliment Pharmacol Ther. 2017;46(3):246-65.

\section{Tables}

Table 1 Characteristics of the studies 


\begin{tabular}{|c|c|c|c|c|c|c|c|c|}
\hline & \multicolumn{5}{|c|}{ Subjects } & \multicolumn{3}{|l|}{$\begin{array}{l}\text { Intervention of } \\
\text { exercise }\end{array}$} \\
\hline $\begin{array}{l}\text { Study name } \\
\text { (year; country) }\end{array}$ & $\mathrm{n}$ & $\begin{array}{l}\text { Female, } \\
\%\end{array}$ & $\begin{array}{l}\text { Mean } \\
\text { age, } \\
\text { years } \\
\text { (SD) }\end{array}$ & $\begin{array}{l}\text { T2DM } \\
\text { duration, } \\
\text { years } \\
\text { (SD) }\end{array}$ & $\begin{array}{l}\text { MED, } \\
\%\end{array}$ & $\begin{array}{l}\text { Description [type, } \\
\text { intensity, time, and } \\
\text { frequency] }\end{array}$ & $\begin{array}{l}\text { Estimated } \\
\text { intensity } \\
\text { of } \\
\text { exercise, } \\
\text { METs }\end{array}$ & $\begin{array}{l}\text { Overall } \\
\text { duration, } \\
\text { weeks }\end{array}$ \\
\hline $\begin{array}{l}\text { Ronnemaa et al. } \\
\text { [47] } \\
\text { (1986; Finland) }\end{array}$ & 25 & 20.0 & $\begin{array}{l}52.5 \\
\text { (NR) }\end{array}$ & $7.1(\mathrm{NR})$ & 92.0 & $\begin{array}{l}\text { Walking, jogging } \\
\text { or skiing, } 70 \% \\
\mathrm{O}_{2 \mathrm{max}}, 45 \\
\text { min/session, and } \\
5-7 \text { sessions/week }\end{array}$ & 7.0 & 17 \\
\hline $\begin{array}{l}\text { Verity et al. [48] } \\
\text { (1989; United } \\
\text { States) }\end{array}$ & 10 & 100 & $\begin{array}{l}59.2 \\
(7.9)\end{array}$ & NR & 0.0 & $\begin{array}{l}\text { Walking, } 65-80 \% \\
\text { HRR, } 60-90 \\
\text { min/week, and } 3 \\
\text { sessions/week }\end{array}$ & 7.6 & 17 \\
\hline $\begin{array}{l}\text { Raz et al. [49] } \\
\text { (1994; Israel) }\end{array}$ & 38 & 63.2 & $\begin{array}{l}56.6 \\
(7.1)\end{array}$ & NR & 100 & $\begin{array}{l}\text { Ergometry bicycle, } \\
\text { treadmill, and } \\
\text { rowing machine, } \\
65 \% \mathrm{O}_{2 \mathrm{max}} 45 \\
\mathrm{~min} / \text { session, and } \\
3 \text { sessions/week }\end{array}$ & 5.7 & 12 \\
\hline $\begin{array}{l}\text { Tessier et al. [50] } \\
\text { (2000; Canada) }\end{array}$ & 39 & 41.0 & $\begin{array}{l}69.4 \\
(7.0)\end{array}$ & $6.5(5.8)$ & 74.4 & $\begin{array}{l}\text { Aerobic training: } \\
\text { waking, 35-79\% } \\
\mathrm{HR}_{\text {max }}, 20 \\
\text { min/session; } \\
\text { aerobic/resistance } \\
\text { training: major } \\
\text { muscle group, } 20 \\
\text { repetitions/set, } 2 \\
\text { sets, } 20 \\
\text { min/session, and } \\
3 \text { sessions/week }\end{array}$ & 5.5 & 16 \\
\hline $\begin{array}{l}\text { Tsujiuchi et al. [51] } \\
\text { (2002; Japan) }\end{array}$ & 26 & NR & $\begin{array}{l}62.9 \\
(7.3)\end{array}$ & NR & NR & $\begin{array}{l}\text { Qi-gong relaxation } \\
\text { exercise, and } 120 \\
\text { min/week }\end{array}$ & 3.0 & 17 \\
\hline $\begin{array}{l}\text { Cuff et al. [52] } \\
\text { (2003a; Canada) }\end{array}$ & 15 & 100 & $\begin{array}{l}62.3 \\
(6.7)\end{array}$ & $4.0(3.1)$ & 73.3 & $\begin{array}{l}\text { Aerobic training: } \\
\text { treadmills, } \\
\text { stationary } \\
\text { bicycles, } \\
\text { recumbent } \\
\text { steppers, elliptical } \\
\text { trainers, and } \\
\text { rowing machines), } \\
60-75 \% \text { HRR; } \\
\text { resistance } \\
\text { training: five } \\
\text { exercises (leg } \\
\text { press, leg curl, hip } \\
\text { extension, chest } \\
\text { press, and } \\
\text { latissimus pull } \\
\text { down), } 12 \\
\text { repetitions/set, } 2 \\
\text { set; total } 75 \\
\text { min/session, and } \\
3 \text { sessions/ week }\end{array}$ & 5.3 & 16 \\
\hline Cuff et al. [52] & 14 & 100 & $\begin{array}{l}59.6 \\
(7.0)\end{array}$ & $3.7(2.6)$ & 71.4 & $\begin{array}{l}\text { Aerobic training } \\
\text { (treadmills, }\end{array}$ & 7.0 & 16 \\
\hline
\end{tabular}

Page 15/31 


\begin{tabular}{|c|c|c|c|c|c|c|c|c|}
\hline (2003b; Canada) & & & & & & $\begin{array}{l}\text { stationary } \\
\text { bicycles, } \\
\text { recumbent } \\
\text { steppers, elliptical } \\
\text { trainers, and } \\
\text { rowing machines), } \\
60-75 \% \text { HRR, } 75 \\
\text { min/session, and } \\
3 \text { sessions/week }\end{array}$ & & \\
\hline $\begin{array}{l}\text { Loimaala et al. [53] } \\
\text { (2003; Finland) }\end{array}$ & 49 & 0.0 & $\begin{array}{l}53.8 \\
(6.3)\end{array}$ & NR & 73.5 & $\begin{array}{l}\text { Aerobic training: } \\
\text { jogging or } \\
\text { walking, 65-75\% } \\
\mathrm{O}_{2 m a x} 30 \\
\text { min/session; } \\
\text { resistance } \\
\text { training: eight } \\
\text { exercises for large } \\
\text { muscle groups } \\
\text { from the trunk and } \\
\text { upper and lower } \\
\text { extremities, 70- } \\
80 \% \text { maximum } \\
\text { voluntary } \\
\text { contraction, 10-12 } \\
\text { repetitions/set, } 3 \\
\text { sets, and 2 } \\
\text { sessions/week }\end{array}$ & 5.1 & 52 \\
\hline $\begin{array}{l}\text { Dela et al. [54] } \\
\text { (2004a; Denmark) }\end{array}$ & 8 & NR & $\begin{array}{l}50.1 \\
(4.3)\end{array}$ & $4.4(2.7)$ & NR & $\begin{array}{l}\text { Ergometer cycle, } \\
40-75 \% \mathrm{O}_{2 \text { max }}, 30- \\
40 \mathrm{~min} / \text { session, } \\
\text { and } 5 \\
\text { sessions/week or } \\
\text { more }\end{array}$ & 6.9 & 12 \\
\hline $\begin{array}{l}\text { Dela et al. [54] } \\
\text { (2004b; Denmark) }\end{array}$ & 16 & NR & $\begin{array}{l}53.6 \\
(8.5)\end{array}$ & $6.0(3.9)$ & NR & $\begin{array}{l}\text { Ergometer cycle, } \\
40-75 \% \mathrm{O}_{2 \text { max }}, 30- \\
40 \mathrm{~min} / \text { session, } \\
\text { and } 5 \\
\text { sessions/week or } \\
\text { more }\end{array}$ & 6.9 & 12 \\
\hline $\begin{array}{l}\text { Bjørgaas et al. [55] } \\
\text { (2005; Norway) }\end{array}$ & 23 & 0.0 & $\begin{array}{l}57.4 \\
(7.5)\end{array}$ & $2.0(\mathrm{NR})$ & 91.3 & $\begin{array}{l}\text { Light jogging, co- } \\
\text { ordination } \\
\text { exercises, knee } \\
\text { bends and } \\
\text { stretching, } 50-85 \% \\
\mathrm{HR}_{\text {max }} 45 \\
\text { min/session; } \\
\text { resistance } \\
\text { exercise: } 15 \\
\text { min/session, and } \\
2 \text { sessions/week }\end{array}$ & 5.6 & 12 \\
\hline $\begin{array}{l}\text { Brooks et al. [56] } \\
\text { (2006; United } \\
\text { States) }\end{array}$ & 62 & 35.5 & $\begin{array}{l}66.0 \\
(7.0)\end{array}$ & $9.5(5.6)$ & 93.5 & $\begin{array}{l}\text { Five exercises } \\
\text { using pneumatic } \\
\text { machines (upper } \\
\text { back, chest press, } \\
\text { leg press, knee } \\
\text { extension, and } \\
\text { flexion), 60-80\% } \\
\text { 1RM, } 8 \\
\text { repetitions/set, } 3 \\
\text { sets, } 35 \\
\text { min/session, and } \\
3 \text { sessions/week }\end{array}$ & 4.4 & 16 \\
\hline
\end{tabular}




\begin{tabular}{|c|c|c|c|c|c|c|c|c|}
\hline $\begin{array}{l}\text { Gordon et al. [57] } \\
\text { (2006; United } \\
\text { States) }\end{array}$ & 30 & 50.0 & $\begin{array}{l}67.0 \\
(8.0)\end{array}$ & $\begin{array}{l}10.5 \\
(9.9)\end{array}$ & 93.3 & $\begin{array}{l}\text { Five exercises } \\
\text { (knee extension, } \\
\text { chest press, leg } \\
\text { curl, upper back, } \\
\text { and leg press), 60- } \\
80 \% \text { of } 1 \text { RM, } 8 \\
\text { repetitions/set, } 3 \\
\text { sets, 45-60 } \\
\text { min/session, and } \\
3 \text { sessions/week }\end{array}$ & 5.0 & 16 \\
\hline $\begin{array}{l}\text { Middlebrooke et al. } \\
\text { [58] } \\
\text { (2006; United } \\
\text { Kingdom) }\end{array}$ & 55 & 53.8 & $\begin{array}{l}63.4 \\
(8.0)\end{array}$ & $4.4(4.3)$ & 55.8 & $\begin{array}{l}\text { Aerobic exercise, } \\
80 \% \mathrm{HR}_{\max }, 30 \\
\mathrm{~min} / \text { session, and } \\
3 \text { sessions/week }\end{array}$ & 5.5 & 26 \\
\hline $\begin{array}{l}\text { Kadoglou et al. } \\
\text { [59] } \\
\text { (2007; Greece) }\end{array}$ & 56 & 58.9 & $\begin{array}{l}61.5 \\
(7.4)\end{array}$ & $6.8(4.1)$ & 90.0 & $\begin{array}{l}\text { Walking or } \\
\text { running on the } \\
\text { treadmill, cycling } \\
\text { and calisthenics } \\
\text { involving the } \\
\text { upper and lower } \\
\text { limbs, } 50-75 \% \\
\mathrm{O}_{2 \text { peak }}, 30-40 \\
\text { min/session, and } \\
4 \text { sessions/week }\end{array}$ & 6.2 & 26 \\
\hline $\begin{array}{l}\text { Lam et al. [60] } \\
\text { (2008; Australia) }\end{array}$ & 44 & 54.5 & $\begin{array}{l}62.1 \\
(9.8)\end{array}$ & NR & NR & $\begin{array}{l}\text { Tai chi (yang and } \\
\text { sun style } 20- \\
\text { form), } 60 \\
\text { min/session, and } \\
1-2 \text { sessions/week }\end{array}$ & 3.0 & 26 \\
\hline $\begin{array}{l}\text { Lambers et al. [61] } \\
\text { (2008a; Belgium) }\end{array}$ & 23 & 54.3 & $\begin{array}{l}56.2 \\
(5.9)\end{array}$ & NR & 97.7 & $\begin{array}{l}\text { Circuit training } \\
\text { (walking or } \\
\text { jogging, elbow } \\
\text { flexion and } \\
\text { extension, cycling, } \\
\text { knee flexion and } \\
\text { extension, and } \\
\text { stepping), } 60-85 \% \\
\text { HRR and } 60-85 \% \\
1 \text { RM, } 50 \\
\text { min/session, and } \\
3 \text { sessions/week }\end{array}$ & 5.6 & 13 \\
\hline $\begin{array}{l}\text { Lambers et al. [61] } \\
\text { (2008b; Belgium) }\end{array}$ & 24 & 18.8 & $\begin{array}{l}53.5 \\
(5.8)\end{array}$ & NR & 97.6 & $\begin{array}{l}\text { Walking (or } \\
\text { jogging), cycling, } \\
\text { stepping, 60-85\% } \\
\text { HRR, } 50 \\
\text { min/session, and } \\
3 \text { sessions/week }\end{array}$ & 8.0 & 13 \\
\hline $\begin{array}{l}\text { Ribeiro et al. [62] } \\
\text { (2008; Brazil) }\end{array}$ & 21 & 66.7 & $\begin{array}{l}55.2 \\
(8.5)\end{array}$ & $8.6(8.0)$ & 85.7 & $\begin{array}{l}\text { Cycle-ergometer, } \\
\text { AT level and } \\
\text { respiratory } \\
\text { compensation } \\
\text { point, } 40 \\
\text { min/session, and } \\
3 \text { sessions/week }\end{array}$ & 7.0 & 17 \\
\hline $\begin{array}{l}\text { Murrock et al. [63] } \\
\text { (2009; United } \\
\text { States) }\end{array}$ & 38 & 100 & $\begin{array}{l}62.6 \\
(7.8)\end{array}$ & $\begin{array}{l}10.3 \\
(\mathrm{NR})\end{array}$ & 78.9 & $\begin{array}{l}\text { Dance, own pace, } \\
45 \mathrm{~min} / \text { session, } \\
\text { and } 2 \\
\text { sessions/week }\end{array}$ & 4.0 & 12 \\
\hline Shenoy et al. [64] & 14 & 57.1 & $\begin{array}{l}52.7 \\
(4.7)\end{array}$ & $5.3(2.1)$ & 92.9 & $\begin{array}{l}\text { Seven exercises } \\
\text { (biceps curls, }\end{array}$ & 4.7 & 16 \\
\hline
\end{tabular}


triceps curls, front

lateral pull down,

back lateral pull

down, knee

extension

exercises,

hamstring curls,

and abdominal

curls), $60-100 \%$

1RM, 10

repetitions/set, 3

sets, and 2

sessions/week

Shenoy et al. [64] $\quad 15 \quad 40.0$

(2009b; India)

(4.5)

Walking, 70\%

$\mathrm{HR}_{\text {max }}, 30$

6.0

16

$\mathrm{min} /$ session, and

3 sessions/week

Church et al. [65

$87 \quad 60.1$

57.2
$(4.5)$

Nine exercises

(bench press,

3.5

seated row,

States)

shoulder press,

pull down, leg

press, extension,

flexion, abdominal

crunches, and

back extensions),

10-12

repetitions/set, 2-3

sets, and 2

sessions/week

(141 min/week)

Church et al. [65] $\quad 86 \quad 63.1$
(2010b; United
States)

$54.5 \quad 7.4(5.9) \quad 93.5$

(4.5)

Aerobic exercise,

$12 \mathrm{kcal} / \mathrm{kg} /$ week,

and 150

$\mathrm{min} /$ week

Church et al. [65

$90 \quad 64.8$

55.9

(4.4)

$6.8(5.4)$

97.8

(2010c; United

States)
Aerobic training:
aerobic exercise,
$10 \mathrm{kcal} / \mathrm{kg} / \mathrm{week}$,
$150 \mathrm{~min} /$ week;
resistance
training: 9
exercises (bench
press, seated row,
shoulder press,
pull down, leg
press, extension,
flexion, abdominal
crunches, and
back extensions),
10-12
repetitions/set, 2-3
sets, and 2
sessions/week

\begin{tabular}{|c|c|c|c|c|c|c|c|c|}
\hline $\begin{array}{l}\text { Hosaka et al. [66] } \\
\text { (2010; Japan) }\end{array}$ & 24 & 58.3 & $\begin{array}{l}59.0 \\
(8.4)\end{array}$ & NR & NR & $\begin{array}{l}\text { Mechanical } \\
\text { horseback riding } \\
\text { apparatus, } 30 \\
\text { min/session, and } \\
7 \text { session/week }\end{array}$ & 4.0 & 13 \\
\hline $\begin{array}{l}\text { Plotnikoff et al. } \\
\text { [67] } \\
\text { (2010; Canada) }\end{array}$ & 48 & 66.7 & $\begin{array}{l}54.6 \\
(9.3)\end{array}$ & NR & NR & $\begin{array}{l}\text { Total of } 8 \\
\text { exercise, } 4 \text { of core } \\
\text { exercises (squats, } \\
\text { seated row, chest } \\
\text { press, shoulder }\end{array}$ & 5.0 & 16 \\
\hline
\end{tabular}




\begin{tabular}{|c|c|c|c|c|c|c|c|c|}
\hline & & & & & & $\begin{array}{l}\text { press) and } 4 \text { of } 9 \\
\text { assistance } \\
\text { exercise (lunges, } \\
\text { lateral pull-down, } \\
\text { standing triceps } \\
\text { extension, } \\
\text { standing pulley } \\
\text { abdominal twists, } \\
\text { biceps curl, triceps } \\
\text { press, reverse } \\
\text { rhomboid flies, } \\
\text { lateral pulley } \\
\text { deltoid raise, or } \\
\text { pulley abdominal } \\
\text { curls), 50-85\% } \\
\text { 1RM, 8-12 } \\
\text { repetitions/set, 2-3 } \\
\text { sets, and } 3 \\
\text { sessions/week }\end{array}$ & & \\
\hline $\begin{array}{l}\text { Reid et al. [68] } \\
\text { (2010a; Canada) }\end{array}$ & 74 & 34.2 & $\begin{array}{l}53.7 \\
(4.9)\end{array}$ & $5.2(4.7)$ & NR & $\begin{array}{l}\text { Aerobic training: } \\
\text { treadmills and/or } \\
\text { bicycle } \\
\text { ergometers, } 60- \\
75 \% \text { HR } \\
\text { max } 45 \\
\text { min; resistance } \\
\text { training: } 8 \\
\text { exercises on } \\
\text { weight machines } \\
\text { each session, } 8 \\
\text { RM, } 8 \text { repetitions, } \\
2-3 \text { sets, and } 3 \\
\text { sessions/week }\end{array}$ & 5.1 & 26 \\
\hline $\begin{array}{l}\text { Reid et al. [68] } \\
\text { (2010b; Canada) }\end{array}$ & 68 & 35.1 & $\begin{array}{l}54.8 \\
(4.8)\end{array}$ & $5.9(4.7)$ & NR & $\begin{array}{l}\text { Eight exercises on } \\
\text { weight machines } \\
\text { each session, } 8 \\
\text { RM, } 8 \text { repetitions, } \\
2-3 \text { sets, and } 3 \\
\text { sessions/week }\end{array}$ & 3.5 & 26 \\
\hline $\begin{array}{l}\text { Reid et al. [68] } \\
\text { (2010c; Canada) }\end{array}$ & 75 & 35.7 & $\begin{array}{l}54.2 \\
(5.1)\end{array}$ & $5.1(3.8)$ & NR & $\begin{array}{l}\text { Treadmills and/or } \\
\text { bicycle } \\
\text { ergometers, 60- } \\
75 \% \mathrm{HR}_{\max }, 45 \\
\text { min, and } 3 \\
\text { sessions/week }\end{array}$ & 6.6 & 26 \\
\hline $\begin{array}{l}\text { Sun et al. [69] } \\
\text { (2010a; United } \\
\text { States) }\end{array}$ & 16 & NR & $\begin{array}{l}56.3 \\
(8.1)\end{array}$ & NR & 100 & $\begin{array}{l}\text { Qigong, } 30-60 \\
\text { min/session, and } \\
3 \text { sessions/week }\end{array}$ & 3.0 & 12 \\
\hline $\begin{array}{l}\text { Sun et al. [69] } \\
\text { (2010b; United } \\
\text { States) }\end{array}$ & 16 & NR & $\begin{array}{l}56.3 \\
(8.1)\end{array}$ & NR & 100 & $\begin{array}{l}\text { Progressive } \\
\text { resistance } \\
\text { training, } 30-60 \\
\text { min/session, and } \\
3 \text { sessions/week }\end{array}$ & 3.5 & 12 \\
\hline $\begin{array}{l}\text { Yavari et al. [70] } \\
\text { (2010; Iran) }\end{array}$ & 60 & 53.3 & $\begin{array}{l}49.8 \\
(6.7)\end{array}$ & $4.5(2.5)$ & 100 & $\begin{array}{l}\text { Aerobic training } \\
\text { (treadmill, bicycle, } \\
\text { elliptical, } \\
\text { ergometers), } 50- \\
75 \% \mathrm{HR}_{\text {max }}, 50-60 \\
\text { min/session, and } \\
3 \text { sessions/week }\end{array}$ & 5.2 & 16 \\
\hline Belli et al. [71] & 19 & 100 & 54.7 & $4.1(3.2)$ & 78.9 & Walking, VT & 7.5 & 12 \\
\hline
\end{tabular}




\begin{tabular}{|c|c|c|c|c|c|c|c|c|}
\hline (2011; Brazil) & & & $(7.4)$ & & & $\begin{array}{l}\text { intensity, } 20-60 \\
\mathrm{~min} / \text { session, and } \\
3 \text { sessions/week }\end{array}$ & & \\
\hline $\begin{array}{l}\text { Kurban et al. [72] } \\
\text { (2011; Turkey) }\end{array}$ & 60 & 51.7 & $\begin{array}{l}53.7 \\
(7.0)\end{array}$ & $6.4(4.9)$ & 100 & $\begin{array}{l}\text { Walking, } \\
\text { moderate- } \\
\text { intensity, } 50 \\
\text { min/session, and } \\
3 \text { sessions/week }\end{array}$ & 4.0 & 13 \\
\hline $\begin{array}{l}\text { Kwon et al. [73] } \\
\text { (2011a; Republic } \\
\text { of Korea) }\end{array}$ & 21 & 100 & $\begin{array}{l}56.8 \\
(5.9)\end{array}$ & $6.0(6.0)$ & 100 & $\begin{array}{l}\text { Brisk walking } \\
\text { using an } \\
\text { accelerometer, } \\
\text { moderate intensity } \\
\text { (3.6-6.0 METs), 60 } \\
\text { min/session, and } \\
5 \text { sessions/week }\end{array}$ & 3.1 & 12 \\
\hline $\begin{array}{l}\text { Kwon et al. [73] } \\
\text { (2011b; Republic } \\
\text { of Korea) }\end{array}$ & 20 & 100 & $\begin{array}{l}57.3 \\
(6.0)\end{array}$ & $4.7(3.6)$ & 100 & $\begin{array}{l}\text { Ten exercises } \\
\text { using bands } \\
\text { (bicep curls, tricep } \\
\text { extensions, } \\
\text { upright rows, } \\
\text { shoulder chest } \\
\text { press, seated } \\
\text { rows, trunk side } \\
\text { bends, leg press, } \\
\text { hip flexions, leg } \\
\text { flexions, and leg } \\
\text { extensions), 1.2- } \\
3.2 \text { kg of } \\
\text { resistance, } 3 \text { sets, } \\
40 \text { min/session, } \\
\text { and } 3 \\
\text { sessions/week }\end{array}$ & 4.8 & 12 \\
\hline $\begin{array}{l}\text { de Oliveira et al. } \\
\text { [74] } \\
\text { (2012a; Brazil) }\end{array}$ & 15 & 58.0 & $\begin{array}{l}52.4 \\
(6.3)\end{array}$ & $5.4(4.0)$ & 100 & $\begin{array}{l}\text { Cycle-ergometer, } \\
\text { LT intensity, 20-50 } \\
\text { min/session, and } \\
3 \text { sessions/week }\end{array}$ & 6.7 & 12 \\
\hline $\begin{array}{l}\text { de Oliveira et al. } \\
\text { [74] } \\
\text { (2012b; Brazil) }\end{array}$ & 14 & 62.1 & $\begin{array}{l}53.9 \\
(6.5)\end{array}$ & $7.0(3.8)$ & 100 & $\begin{array}{l}\text { Circuit of } 7 \\
\text { exercises (leg } \\
\text { press, bench } \\
\text { press, lat pull } \\
\text { down, seated } \\
\text { rowing, shoulder } \\
\text { press, abdominal } \\
\text { curls, and knees } \\
\text { curls), 50\% 1RM } \\
\text { or } 8-12 \text { RM, 15 } \\
\text { repetitions/set, 1-4 } \\
\text { sets, and 3 } \\
\text { sessions/week }\end{array}$ & 4.9 & 12 \\
\hline $\begin{array}{l}\text { de Oliveira et al. } \\
\text { [74] } \\
\text { (2012c; Brazil) }\end{array}$ & 14 & 62.1 & $\begin{array}{l}56.6 \\
(6.5)\end{array}$ & $6.7(4.6)$ & 100 & $\begin{array}{l}\text { Aerobic training: } \\
\text { cycle-ergometer, } \\
\text { LT intensity, 10-25 } \\
\text { min/session; } \\
\text { resistance } \\
\text { training: circuit of } \\
7 \text { exercises (leg } \\
\text { press, bench } \\
\text { press, lat pull } \\
\text { down, seated } \\
\text { rowing, shoulder } \\
\text { press, abdominal } \\
\text { curls, and knees } \\
\text { curls), } 50 \% 1 \mathrm{RM}\end{array}$ & 4.0 & 12 \\
\hline
\end{tabular}


or 8-12 RM, 15

repetitions/set, 1-4

sets; half the

volume of aerobic

and resistance

training, and 3

sessions/week

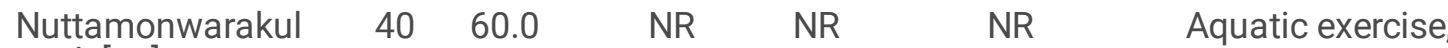

et al. [75]

$70 \% \mathrm{HR}_{\text {max }}, 30$

4.5

$\mathrm{min} / \mathrm{session}$, and

(2012; Thailand)

3 sessions/week

Swift et al. [76]

$\begin{array}{ll}62 & 62.4\end{array}$

56.3
$(5.1)$

$7.5(5.7)$

94.7

Aerobic exercise,

$50-80 \% \mathrm{O}_{2 \max }$

8.0

39

(2012a; United

and 122

States)

$\mathrm{min} /$ week

(average)

Swift et al. [76

$\begin{array}{ll}70 & 58.1\end{array}$

58.7

(4.8)

Nine exercises
(bench press,
seated row,
shoulder press,
pull down, leg
press, extension,
flexion, abdominal
crunches, and
back extensions),
2-3 sets, 10-12
repetitions, and 3
sessions/week

(2012b; United

States)

$7.6(5.6)$

99.6

3.5

39

Swift et al. [76]

$\begin{array}{llll}71 & 63.0 & 57.0 & 6.8(5.5)\end{array}$

(4.7)

Aerobic training:

aerobic exercise,

5.8

(2012c; United

States)

$50-80 \% \quad \mathrm{O}_{2 \text { max }}$;

resistance

training: 9

exercises (bench

press, seated row,

shoulder press,

pull down, leg

press, extension,

flexion, abdominal

crunches, and

back extensions),

10-12

repetitions/set, 2-3

sets and 106

min/week

(average)

Tan et al. [77]

(2012; China)

2564.

64.0

65.5

(6.7)

16.2
$(6.9)$
Aerobic training:

walking/running,

$55-70 \% \mathrm{HR}_{\max }, 30$

min; resistance

training: 5 leg

exercise (knee

flexion, knee

extension, hip

abduction, hip

adduction, and

standing calf

raise), $50-70 \%$

1RM, 10-12

repetitions/set, 2

set, $10 \mathrm{~min}$, and 3

sessions/week 


\begin{tabular}{|c|c|c|c|c|c|c|c|c|}
\hline $\begin{array}{l}\text { Fritz et al. [78] } \\
\text { (2013; Sweden) }\end{array}$ & 47 & 34.0 & $\begin{array}{l}61.2 \\
(7.2)\end{array}$ & $5.1(3.7)$ & 64.0 & $\begin{array}{l}\text { Nordic walking, a } \\
\text { pace with slight } \\
\text { shortness of } \\
\text { breath and } \\
\text { perspiration, and } \\
3.9 \text { hours/week }\end{array}$ & 3.5 & 17 \\
\hline $\begin{array}{l}\text { Karstoft et al. [79] } \\
\text { (2013a; Denmark) }\end{array}$ & 16 & 34.4 & $\begin{array}{l}59.9 \\
(5.7)\end{array}$ & $5.8(5.0)$ & 59.4 & $\begin{array}{l}\text { Continuous- } \\
\text { walking, } 55 \% \text { of } \\
\text { the peak energy- } \\
\text { expenditure, } 60 \\
\text { min/session, and } \\
5 \text { sessions/week }\end{array}$ & 5.5 & 17 \\
\hline $\begin{array}{l}\text { Karstoft et al. [79] } \\
\text { (2013b; Denmark) }\end{array}$ & 16 & 40.6 & $\begin{array}{l}57.4 \\
(5.7)\end{array}$ & 3.8 (3.0) & 59.4 & $\begin{array}{l}\text { Interval-walking, } \\
\text { consisting of } \\
3 \text { min fast walking } \\
\text { and } 3 \text { min slow } \\
\text { walking above or } \\
\text { below the targeted } \\
\text { of } 70 \% \text { of the } \\
\text { peak energy- } \\
\text { expenditure, } 60 \\
\text { min/session, and } \\
5 \text { sessions/week }\end{array}$ & 5.5 & 17 \\
\hline $\begin{array}{l}\text { Sparks et al. [80] } \\
\text { (2013a; } \\
\text { Netherlands) }\end{array}$ & 15 & 58.0 & $\begin{array}{l}55.5 \\
(5.0)\end{array}$ & $6.6(6.0)$ & NR & $\begin{array}{l}\text { Aerobic exercise, } \\
50-80 \% \mathrm{O}_{2 \text { peak }} \\
\text { and } 150 \\
\text { min/week }\end{array}$ & 8.0 & 39 \\
\hline $\begin{array}{l}\text { Sparks et al. [80] } \\
\text { (2013b; } \\
\text { Netherlands) }\end{array}$ & 21 & 55.7 & $\begin{array}{l}55.4 \\
(5.0)\end{array}$ & $8.8(6.4)$ & NR & $\begin{array}{l}\text { Nine exercises } \\
\text { (bench press, } \\
\text { seated row, } \\
\text { shoulder press, lat } \\
\text { pull down, leg } \\
\text { press, leg } \\
\text { extension, leg } \\
\text { flexion, abdominal } \\
\text { crunches, and } \\
\text { back extensions), } \\
10-12 \\
\text { repetitions/set, 2-3 } \\
\text { sets, 45-50 } \\
\text { min/session, and } \\
3 \text { sessions/week }\end{array}$ & 3.5 & 39 \\
\hline $\begin{array}{l}\text { Sparks et al. [80] } \\
\text { (2013c; } \\
\text { Netherlands) }\end{array}$ & 15 & 58.0 & $\begin{array}{l}60.5 \\
(4.2)\end{array}$ & $6.1(4.0)$ & NR & $\begin{array}{l}\text { Aerobic training: } \\
\text { aerobic exercise, } \\
50-80 \% \quad 0_{2 p e a k} \\
\text { and } 125 \\
\text { min/week; } \\
\text { resistance } \\
\text { training: } 9 \\
\text { exercises (bench } \\
\text { press, seated row, } \\
\text { shoulder press, lat } \\
\text { pull down, leg } \\
\text { press, leg } \\
\text { extension, leg } \\
\text { flexion, abdominal } \\
\text { crunches, and } \\
\text { back extensions), } \\
10-12 \\
\text { repetitions/set, } 1 \\
\text { sets, } 45-50 \\
\text { min/session and } \\
2 \text { sessions/week }\end{array}$ & 7.8 & 39 \\
\hline
\end{tabular}


Youngwanichsetha $64 \quad 100$ et al. [81]

(2013; Thailand)

Mitranun et al. [82]

$22 \quad 63.6$

(2014a; Thailand)

35.6

$2.6(1.2) \quad 0.0$

Tai chi qigong

3.0

12

exercise, 50

$\mathrm{min} / \mathrm{session}$, and

3 sessions/week

Continuous

aerobic training,

$50-65 \% \mathrm{O}_{2 \text { peak, }}, 30$

$\mathrm{min} / \mathrm{session}$, and

3 sessions/week

Mitranun et al. [82]

$22 \quad 63.6$

$61.1 \quad 20.3$

(7.3) (1.7)

(2014b; Thailand)

(7.3) (1.7)

Interval aerobic

training, 50-85\%

$\mathrm{O}_{2 \text { peak }}, 30$

$\mathrm{min} /$ session, and

3 session/week

\begin{tabular}{|c|c|c|}
\hline Yan et al. [83] & 41 & 0.0 \\
\hline
\end{tabular}

Dede et al. [84] $\quad 60 \quad 51.7$
(2015; Turkey)

53.5
$(5.9)$

$60 \quad 51.7$

$54.0 \quad 6.4(4.9) \quad 100$

(7.9)

NR

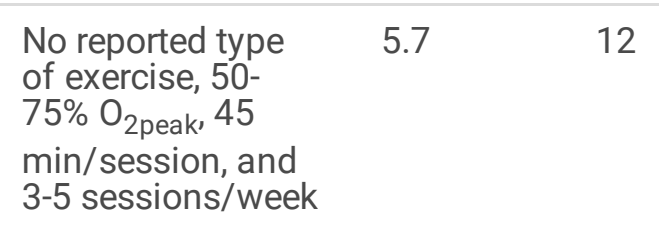

Aerobic exercise

on a treadmill, 60-

6.5

12

$75 \% \mathrm{HR}_{\max }, 45$

$\mathrm{min} / \mathrm{session}$, and

3 sessions/week

$\begin{array}{lll}56.1 & 7.4(5.7) \quad N R\end{array}$

(8.5)

Brisk walking,
jogging or riding
an exercise bike,
$60-80 \% \mathrm{HR}_{\text {max }}, 30$
min/session, and
5 sessions/week

Park et al. [86]

$37 \quad 54.1$

$70.7 \quad N R$

(5.4)

97.3

(2015; Republic of

Korea)

$5.8 \quad 12$

jog

\begin{tabular}{|c|c|c|c|c|c|}
\hline $\begin{array}{l}\text { Xiao et al. [87] } \\
\text { (2015; China) }\end{array}$ & 32 & NR & $\begin{array}{l}65.5 \\
\text { (NR) }\end{array}$ & NR & NR \\
\hline $\begin{array}{l}\text { Cassidy et al. [88] } \\
\text { (2016; United } \\
\text { Kingdom) }\end{array}$ & 23 & 21.7 & $\begin{array}{l}60.0 \\
(8.2)\end{array}$ & $4.5(2.6)$ & 100 \\
\hline
\end{tabular}

Page 23/31

Circuit training:
strengthening
exercise, 6
exercises (leg
extension, leg curl,
seated rowing,
seated chest
press, abdominal
crunch, and lower
back extension),
65-75\% 1RM, 10-
12 repetitions/set,
1-3 sets; aerobic
exercise,
stationary bicycle
and cross-walker,
9-14 RPE, 3-5
min/set, 1-3 sets,
40 min/session,
and 3
sessions/week
Tai chi ball, 60-
120 min/session,
and 3
sessions/week
High intensity
intermittent
training: cycle 4.8
ergometry, RPE 9-




\begin{tabular}{|c|c|c|c|c|c|c|c|c|}
\hline & & & & & & $\begin{array}{l}\text { 17, } 4-5 \text { min/set, } 5 \\
\text { set; resistance } \\
\text { training: } 4 \\
\text { exercises using } \\
\text { bands (face pull, } \\
\text { horizontal push, } \\
\text { horizontal pull, } \\
\text { and } 30^{\circ} \text { push), } 1 \\
\text { min/set, } 4 \text { set, and } \\
3 \text { sessions/week }\end{array}$ & & \\
\hline $\begin{array}{l}\text { Keshavarz et al. } \\
\text { [89] } \\
\text { (2016; Iran) }\end{array}$ & 20 & 100 & $\begin{array}{l}49.4 \\
(6.2)\end{array}$ & $7.6(4.3)$ & 100 & $\begin{array}{l}\text { Rhythmic } \\
\text { movements, } 60 \% \\
\mathrm{HR}_{\text {max }}, 20-45 \\
\text { min/session, and } \\
3 \text { session/week }\end{array}$ & 3.8 & 12 \\
\hline $\begin{array}{l}\text { Tomas-Carus et al. } \\
\text { [90] } \\
\text { (2016; Portugal) }\end{array}$ & 30 & 43.3 & $\begin{array}{l}59.4 \\
(6.3)\end{array}$ & $\begin{array}{l}10.4 \\
(7.0)\end{array}$ & NR & $\begin{array}{l}\text { Aerobic exercise: } \\
60-65 \% \mathrm{HR}_{\text {max }}, 25 \\
\text { min/session; } \\
\text { resistance } \\
\text { exercise: lower } \\
\text { and upper limbs } \\
\text { (using subject's } \\
\text { own weight as } \\
\text { resistance, light } \\
\text { weight loads, or } \\
\text { soft rubber } \\
\text { bands), } 15 \\
\text { min/session, and } \\
3 \text { sessions/week }\end{array}$ & 4.0 & 12 \\
\hline $\begin{array}{l}\text { Annibalini et al. } \\
\text { [91] } \\
\text { (2017; Italy) }\end{array}$ & 16 & 0.0 & $\begin{array}{l}58.5 \\
(7.3)\end{array}$ & $9.0(6.3)$ & 100 & $\begin{array}{l}\text { Aerobic training: } \\
\text { walking, 40-65\% } \\
\text { HRR, 60 } \\
\text { min/session; } \\
\text { resistance } \\
\text { training: } 4 \\
\text { exercises } \\
\text { (horizontal leg } \\
\text { press, lat pull-- } \\
\text { down, lat } \\
\text { machine, and } \\
\text { chest press), 40- } \\
60 \% 1 \mathrm{RM}, 12-20 \\
\text { repetitions/set, 2-4 } \\
\text { sets, and 2-3 } \\
\text { sessions/week }\end{array}$ & 5.7 & 16 \\
\hline $\begin{array}{l}\text { Botton et al. [92] } \\
\text { (2018; Brazil) }\end{array}$ & 26 & 42.3 & $\begin{array}{l}69.6 \\
(7.7)\end{array}$ & $\begin{array}{l}11.0 \\
(7.7)\end{array}$ & 100 & $\begin{array}{l}\text { Functional } \\
\text { exercises (squat } \\
\text { and steps up and } \\
\text { down), additional } \\
\text { load or step if < } 6 \\
\text { on OMNl scale, } \\
10-15 \\
\text { repetitions/set, 2-3 } \\
\text { sets; traditional } \\
\text { exercises: } 9 \\
\text { exercises (leg } \\
\text { press, leg } \\
\text { extension, leg curl, } \\
\text { hip abduction, } \\
\text { inclined bench } \\
\text { press, low row, } \\
\text { biceps curl, } \\
\text { triceps, and } \\
\text { crunch), } 12-15 \\
\text { RM, } 10-12\end{array}$ & 3.0 & 12 \\
\hline
\end{tabular}




\begin{tabular}{|c|c|c|c|c|c|c|c|c|}
\hline & & & & & & $\begin{array}{l}\text { repetitions/set, 2-3 } \\
\text { sets, and } 3 \\
\text { sessions/week }\end{array}$ & & \\
\hline $\begin{array}{l}\text { Hsieh et al. [93] } \\
\text { (2018; Taiwan) }\end{array}$ & 30 & 63.3 & $\begin{array}{l}71.2 \\
(6.8)\end{array}$ & $\begin{array}{l}12.5 \\
(7.3)\end{array}$ & NR & $\begin{array}{l}\text { Eight exercises } \\
\text { (chest press, } \\
\text { shoulder press, } \\
\text { biceps curl, hip } \\
\text { abduction, } \\
\text { standing hip } \\
\text { flexion, leg press, } \\
\text { standing calf } \\
\text { raise, and } \\
\text { abdominal } \\
\text { crunch), 40-75\% } \\
\text { 1RM (or Borg } \\
\text { scale } 12-16), 8-12 \\
\text { repetitions/set, } 3 \\
\text { sets, and 3 } \\
\text { sessions/week }\end{array}$ & 8.0 & 12 \\
\hline $\begin{array}{l}\text { Stubbs et al. [94] } \\
\text { (2019a; United } \\
\text { States) }\end{array}$ & 15 & 6.7 & $\begin{array}{l}61.7 \\
(5.4)\end{array}$ & $\begin{array}{l}11.4 \\
(6.7)\end{array}$ & 100 & $\begin{array}{l}\text { Treadmill walking, } \\
71-90 \% \mathrm{O}_{2 \text { peak }}, 30- \\
45 \mathrm{~min} / \text { session, } \\
\text { and } 3 \\
\text { sessions/week }\end{array}$ & 6.8 & 12 \\
\hline $\begin{array}{l}\text { Stubbs et al. [94] } \\
\text { (2019b; United } \\
\text { States) }\end{array}$ & 15 & 0.0 & $\begin{array}{l}63.3 \\
(5.4)\end{array}$ & $\begin{array}{l}10.8 \\
(8.1)\end{array}$ & 100 & $\begin{array}{l}\text { Leg extensions, } 10 \\
\text { repetitions/set, 3-6 } \\
\text { sets, and } 3 \\
\text { sessions/week }\end{array}$ & 2.8 & 12 \\
\hline $\begin{array}{l}\text { Stubbs et al. [94] } \\
\text { (2019c; United } \\
\text { States) }\end{array}$ & 15 & 6.7 & $\begin{array}{l}62.5 \\
(5.4)\end{array}$ & $9.9(7.9)$ & 100 & $\begin{array}{l}\text { Aerobic training: } \\
\text { treadmill walking, } \\
71-90 \% \quad \mathrm{O}_{2 \text { peak, }} \\
30-45 \\
\text { min/session; } \\
\text { resistance } \\
\text { training: leg } \\
\text { extensions, } 10 \\
\text { repetitions/set, 3-6 } \\
\text { sets, and 3 } \\
\text { sessions/week }\end{array}$ & 6.4 & 12 \\
\hline
\end{tabular}

AT, anaerobic threshold; $\mathrm{HR}_{\text {max }}$, maximum heart rate; $\mathrm{HRR}$, heart rate reserve; $\mathrm{LT}$, lactate threshold; MED, subjects taking medication; $n$, number of subjects; NR, not reported; RM, repetition maximum; T2DM, type 2 diabetes mellitus; $\mathrm{O}_{2 \text { max }}$ maximal oxygen uptake; VT, ventilation threshold

Table 2 Baseline and form of exercise data 


\begin{tabular}{|ll|}
\hline Characteristic & \\
\hline Female [n (\%)] & $1192(52.4)$ \\
\hline Age, years [mean (SD)] & $55.2(6.4)$ \\
\hline BMI, kg/m² [mean (SD)] & $31.4(5.0)$ \\
\hline Duration of T2DM, years [mean (SD)] & $7.2(5.1)$ \\
\hline Subjects with medication, \% [mean (SD)] & $88.1(21.9)$ \\
\hline Intensity of exercise, METs [mean (SD)] & $5.1(1.4)$ \\
\hline Time of exercise, min/session [mean (SD)] & $54(17)$ \\
\hline Frequency of exercise, sessions/week [mean (SD)] & $3.2(0.9)$ \\
\hline Overall duration of exercise, weeks [mean (SD)] & $21.5(11.3)$ \\
\hline
\end{tabular}

BMI, body mass index; METs, metabolic equivalents; $n$, number of subjects; SD, standard deviation; T2DM, type 2 diabetes mellitus.

Table 3 Results of sensitivity analyses of study on $\mathrm{HbA}_{1 \mathrm{c}}$

\begin{tabular}{|llllcc|}
\hline Category & $\mathrm{N}(\mathrm{n})$ & Baseline (SD) & Pooled WMD (95\% Cl) & Q & $\mathrm{I}^{2}(\%)$ \\
\hline Mean age $\geq 40$ years & $47(2331)$ & $7.6(1.3)$ & $-0.5(-0.6$ to -0.4$)$ & $103.1^{\square}$ & 37.0 \\
\hline Mean baseline $\mathrm{HbA}_{1 \mathrm{c}} \geq 6.5 \%$ & $47(2370)$ & $7.6(1.3)$ & $-0.5(-0.6$ to -0.4$)$ & $103.7^{\square}$ & 37.4 \\
\hline Mean duration of T2DM $\geq 5.0$ years & $28(1598)$ & $7.5(1.1)$ & $-0.5(-0.6$ to -0.4$)$ & $73.2^{\square}$ & 42.0 \\
\hline Mean baseline BMI $\geq 30 \mathrm{~kg} / \mathrm{m}^{2}$ & $29(1701)$ & $7.6(1.2)$ & $-0.4(-0.5$ to -0.3$)$ & $73.8^{\square}$ & 39.9 \\
\hline Calculation of the WMD in BMI & $35(1730)$ & $7.6(1.3)$ & $-0.4(-0.5$ to -0.3$)$ & $79.7^{\square}$ & 38.3 \\
\hline Aerobic exercise alone & $28(1046)$ & $7.7(1.4)$ & $-0.5(-0.7$ to -0.3$)$ & $45.7^{\square}$ & 39.6 \\
\hline Did not include a high risk of bias & $42(2183)$ & $7.5(1.2)$ & $-0.5(-0.6$ to -0.4$)$ & $98.6^{\square}$ & 42.3 \\
\hline
\end{tabular}

$\mathrm{Cl}$, confidence interval; $\mathrm{HbA}_{1 \mathrm{c}}$, hemoglobin $\mathrm{A} 1 \mathrm{c} ; \mathrm{N}$, number of trials; $\mathrm{n}$, number of subjects; $\mathrm{SD}$, standard deviation; T2DM, type 2 diabetes mellitus; WMD, weighted mean difference. "Significant heterogeneity $(P<0.05)$.

Table 4 The relationship between the WMD in $\mathrm{HbA}_{1 \mathrm{c}}$ and the intensity or time of exercise according to a meta-regression analysis and sensitivity analysis 


\begin{tabular}{|c|c|c|c|c|c|c|c|c|}
\hline \multirow[b]{2}{*}{ Category } & \multicolumn{4}{|c|}{ Intensity of exercise (METs) } & \multicolumn{4}{|c|}{ Time of exercise (min/session) } \\
\hline & $\operatorname{MRC}(95 \% \mathrm{Cl})$ & $\begin{array}{l}\mathrm{R}^{2} \\
\%\end{array}$ & Q & $\mathrm{I}^{2}, \%$ & $\begin{array}{l}\mathrm{MRC}(95 \% \\
\mathrm{Cl})\end{array}$ & $\begin{array}{l}\mathrm{R}^{2} \\
\%\end{array}$ & Q & $\mathrm{I}^{2}, \%$ \\
\hline Trials not limited & $\begin{array}{l}0.01(-0.05 \text { to } \\
0.07)\end{array}$ & 41.5 & 81.7 & 24.4 & $\begin{array}{l}0.01(-0.34 \\
\text { to } 0.36)\end{array}$ & 47.2 & 71.7 & 21.4 \\
\hline Mean age $\geq 40$ years & $\begin{array}{l}0.01(-0.06 \text { to } \\
0.07)\end{array}$ & 42.6 & 81.5 & 25.0 & $\begin{array}{l}0.01(-0.34 \\
\text { to } 0.36)\end{array}$ & 44.4 & 71.6 & 22.2 \\
\hline $\begin{array}{l}\text { Mean baseline } \mathrm{HbA}_{1 \mathrm{c}} \\
\geq 6.5 \%\end{array}$ & $\begin{array}{l}0.01(-0.05 \text { to } \\
0.07)\end{array}$ & 47.3 & 79.6 & 23.5 & $\begin{array}{l}0.02(-0.33 \\
\text { to } 0.36)\end{array}$ & 50.9 & 69.9 & 20.5 \\
\hline $\begin{array}{l}\text { Mean duration of T2DM } \\
\geq 5.0 \text { years }\end{array}$ & $\begin{array}{l}0.02(-0.05 \text { to } \\
0.10)\end{array}$ & 30.2 & $56.9^{\square}$ & 32.6 & $\begin{array}{l}-0.22 \\
(-0.76 \text { to } \\
0.33)\end{array}$ & 34.0 & $48.5^{\square}$ & 29.1 \\
\hline $\begin{array}{l}\text { Mean baseline } \mathrm{BMI} \geq \\
30 \mathrm{~kg} / \mathrm{m}^{2}\end{array}$ & $\begin{array}{l}-0.02(-0.09 \\
\text { to } 0.05)\end{array}$ & 54.0 & 51.6 & 22.4 & $\begin{array}{l}0.13(-0.27 \\
\text { to } 0.54)\end{array}$ & 54.0 & 46.1 & 21.0 \\
\hline $\begin{array}{l}\text { Calculation of the WMD } \\
\text { in BMI }\end{array}$ & $\begin{array}{l}0.02(-0.05 \text { to } \\
0.08)\end{array}$ & 42.9 & 58.9 & 25.5 & $\begin{array}{l}0.08(-0.34 \\
\text { to } 0.49)\end{array}$ & 44.9 & 51.9 & 22.6 \\
\hline Aerobic exercise alone & $\begin{array}{l}0.08(-0.01 \text { to } \\
0.17)\end{array}$ & 62.9 & 30.7 & 18.3 & $\begin{array}{l}-0.06 \\
(-0.67 \text { to } \\
0.54)\end{array}$ & 33.9 & 32.9 & 26.5 \\
\hline $\begin{array}{l}\text { Did not include a high } \\
\text { risk of bias }\end{array}$ & $\begin{array}{l}0.01(-0.05 \text { to } \\
0.08)\end{array}$ & 42.6 & $77.3^{\square}$ & 29.0 & $\begin{array}{l}0.00(-0.36 \\
\text { to } 0.36)\end{array}$ & 44.3 & 67.3 & 26.3 \\
\hline
\end{tabular}

$\mathrm{BMI}$, body mass index; $\mathrm{Cl}$, confidence interval; $\mathrm{HbA}_{1 \mathrm{c}}$, hemoglobin A1c; METs, metabolic equivalents; MRC, metaregression coefficient; T2DM, type 2 diabetes mellitus; WMD, weighted mean difference. ${ }^{\square}$ Significant heterogeneity $(P<0.05)$.

Table 5 The relationship between the WMD in $\mathrm{HbA}_{1 \mathrm{c}}$ and the frequency or overall duration of exercise according to a meta-regression analysis and sensitivity analysis 


\begin{tabular}{|c|c|c|c|c|c|c|c|c|}
\hline \multirow[b]{2}{*}{ Category } & \multicolumn{4}{|c|}{ Frequency of exercise (sessions/week) } & \multicolumn{4}{|c|}{ Overall duration of exercise (weeks) } \\
\hline & $\operatorname{MRC}(95 \% \mathrm{Cl})$ & $\begin{array}{l}\mathrm{R}^{2} \\
\%\end{array}$ & Q & $1^{2}, \%$ & $\begin{array}{l}\mathrm{MRC}(95 \% \\
\mathrm{Cl})\end{array}$ & $\begin{array}{l}\mathrm{R}^{2} \\
\%\end{array}$ & Q & $\mathrm{I}^{2}, \%$ \\
\hline Trials not limited & $\begin{array}{l}-0.04(-0.16 \\
\text { to } 0.08)\end{array}$ & 54.7 & 70.7 & 18.7 & $\begin{array}{l}0.01(0.002 \\
\text { to } 0.016)\end{array}$ & 70.0 & 72.3 & 14.7 \\
\hline Mean age $\geq 40$ years & $\begin{array}{l}-0.04(-0.16 \\
\text { to } 0.08)\end{array}$ & 53.7 & 70.5 & 19.5 & $\begin{array}{l}0.01(0.002 \\
\text { to } 0.016)\end{array}$ & 68.5 & 72.3 & 15.4 \\
\hline $\begin{array}{l}\text { Mean baseline } \mathrm{HbA}_{1 \mathrm{c}} \\
\geq 6.5 \%\end{array}$ & $\begin{array}{l}-0.05(-0.17 \\
\text { to } 0.07)\end{array}$ & 60.0 & 68.6 & 17.5 & $\begin{array}{l}0.01(0.002 \\
\text { to } 0.017)\end{array}$ & 74.5 & 69.8 & 13.1 \\
\hline $\begin{array}{l}\text { Mean duration of T2DM } \\
\geq 5.0 \text { years }\end{array}$ & $\begin{array}{l}0.03(-0.15 \text { to } \\
0.20)\end{array}$ & 32.1 & $49.8^{\square}$ & 29.0 & $\begin{array}{l}0.01(0.002 \\
\text { to } 0.018)\end{array}$ & 67.9 & 48.1 & 18.5 \\
\hline $\begin{array}{l}\text { Mean baseline } \mathrm{BMI} \geq 30 \\
\mathrm{~kg} / \mathrm{m}^{2}\end{array}$ & $\begin{array}{l}-0.21(-0.46 \\
\text { to } 0.04)\end{array}$ & 62.0 & 51.3 & 17.4 & $\begin{array}{l}0.01(0.003 \\
\text { to } 0.018)\end{array}$ & 72.0 & 47.2 & 17.0 \\
\hline $\begin{array}{l}\text { Calculation of the WMD } \\
\text { in BMI }\end{array}$ & $\begin{array}{l}-0.12(-0.29 \\
\text { to } 0.05)\end{array}$ & 63.3 & 48.7 & 16.3 & $\begin{array}{l}0.01(0.002 \\
\text { to } 0.017)\end{array}$ & 69.4 & 51.4 & 15.2 \\
\hline Aerobic exercise alone & $\begin{array}{l}0.28(-0.15 \text { to } \\
0.20)\end{array}$ & 35.5 & 33.0 & 26.6 & $\begin{array}{l}0.01(0.003 \\
\text { to } 0.024)\end{array}$ & 99.9 & 27.3 & 0.0 \\
\hline $\begin{array}{l}\text { Did not include a high } \\
\text { risk of bias }\end{array}$ & $\begin{array}{l}-0.03(-0.17 \\
\text { to } 0.11)\end{array}$ & 50.8 & 66.7 & 24.0 & $\begin{array}{l}0.01(0.002 \\
\text { to } 0.017)\end{array}$ & 70.5 & 67.2 & 17.0 \\
\hline
\end{tabular}

$\mathrm{BMI}$, body mass index; $\mathrm{Cl}$, confidence interval; $\mathrm{HbA}_{1 \mathrm{c}}$, hemoglobin $\mathrm{A} 1 \mathrm{c}$; MRC, meta-regression coefficient; T2DM, type 2 diabetes mellitus; WMD, weighted mean difference. ${ }^{\square}$ Significant heterogeneity $(P<0.05)$.

\section{Figures}




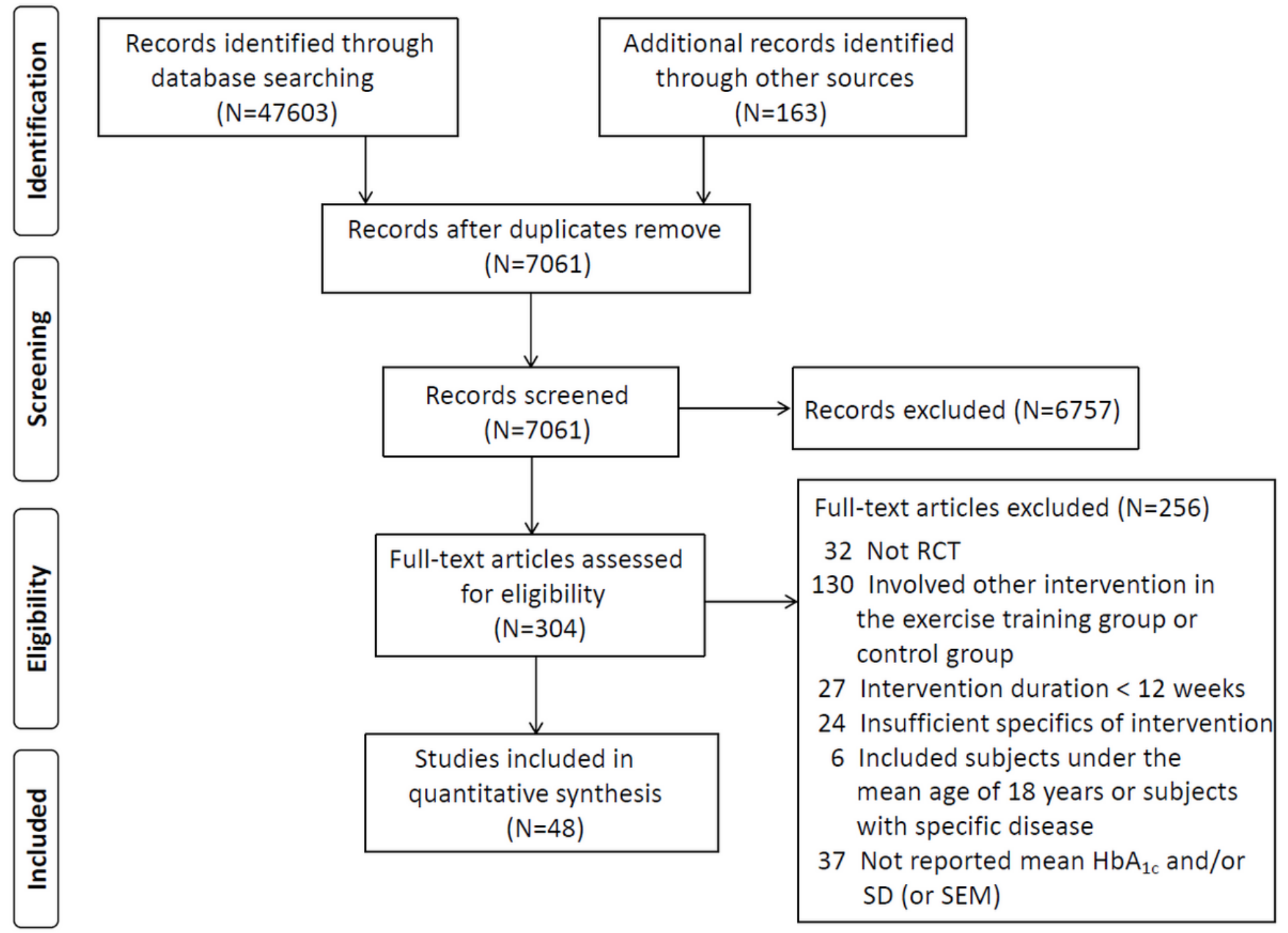

Figure 1

PRISMA flow diagram regarding article selection for meta-analysis. HbA1c, hemoglobin A1c; RCT, randomized controlled trial; SD, standard deviation; SEM, standard error of mean. 


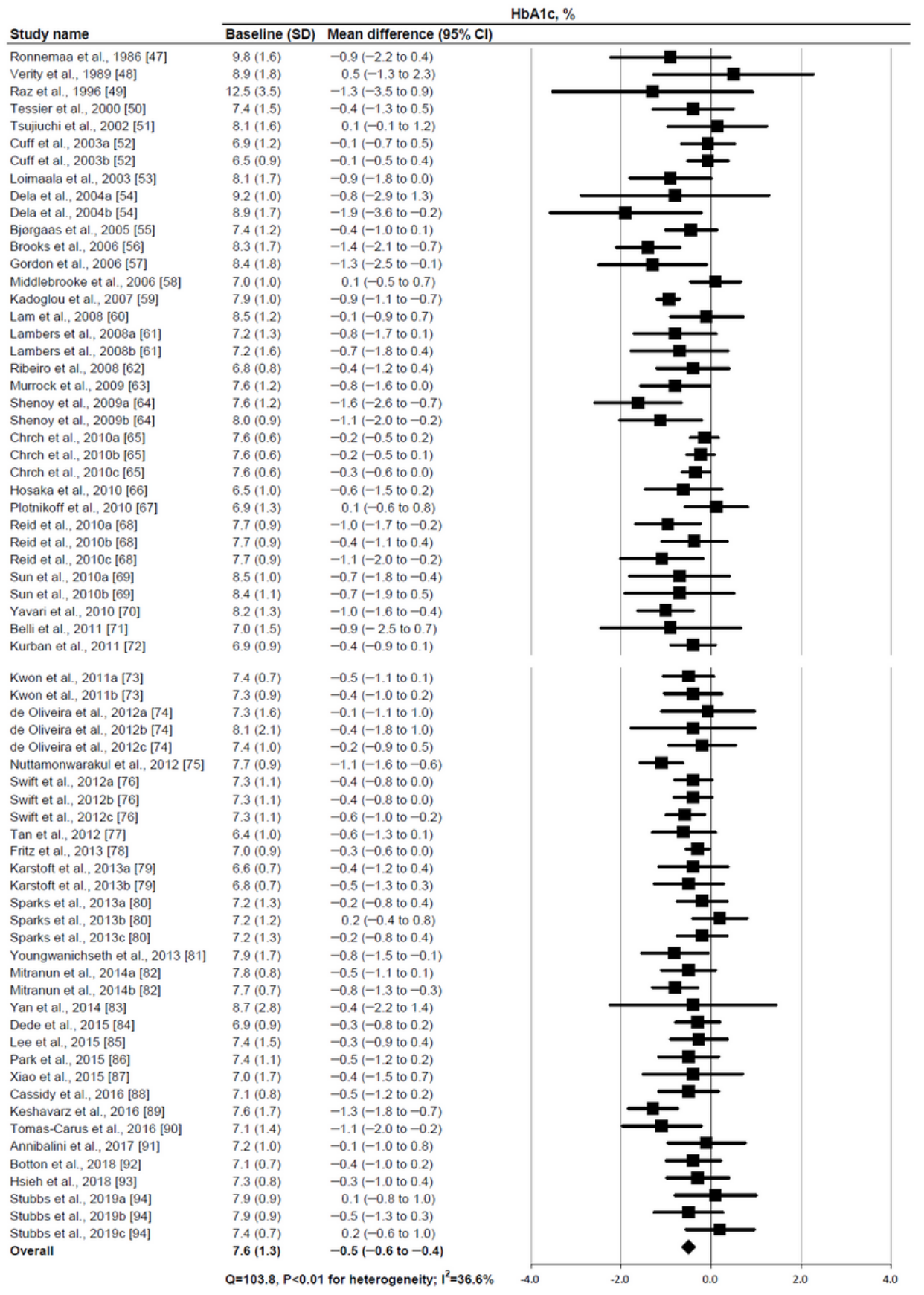

\section{Figure 2}

Baseline mean $\mathrm{HbA} 1 \mathrm{c}$ and forest plot for the WMD in the HbA1c. Each study is presented by black squares (WMD) and width $(95 \% \mathrm{Cl})$. The pooled WMD is represented by black rhombuses and widths $(95 \% \mathrm{Cl})$. HbA1c, hemoglobin A1c; WMD, weighted mean difference.

\section{Supplementary Files}

This is a list of supplementary files associated with this preprint. Click to download.

- PRISMAChecklist.pdf

- SupplementaryMaterial1.pdf

- SupplementaryMaterial2.pdf 
- SupplementaryMaterial3.pdf

- SupplementaryMaterial4.pdf

- SupplementaryMaterial5.pdf 